\title{
Inhibitory Circuitry in the Ventral Cochlear Nucleus is Probably Mediated by Glycine
}

\author{
Shu Hui Wu and Donata Oertel \\ Department of Neurophysiology, University of Wisconsin, Madison, Wisconsin 53706
}

Intracellular recordings from brain slice preparations of the ventral cochlear nuclei (VCN) of mice have shown that both the major cell types, stellate and bushy cells, distinguishable by their responses to intracellularly injected current (Oertel, 1983; Wu and Oertel, 1984), receive late inhibitory as well as early excitatory inputs when the auditory nerve is stimulated electrically.

When the extracellular $\mathrm{Cl}^{-}$concentration was lowered or when the intracellular $\mathrm{Cl}^{-}$was raised, the reversal potential of IPSPs became more positive; the reversal potentials were independent of the extracellular $\mathrm{K}^{+}$concentration. Therefore, IPSPs result from increases in $\mathrm{Cl}^{-}$permeability. To determine whether either or both GABA or glycine might mediate the inhibition, the sensitivity of cells to bath-applied putative neurotransmitters was tested. All cells responded to applications of 0.1-10 mM GABA and glycine with large drops in input resistance; these drops were $\mathrm{Cl}^{-}$dependent. To determine which of these 2 substances was more likely to mediate the IPSPs, antagonists specific to GABA and glycine were tested for their ability to block the IPSPs. All IPSPs were eliminated by $1 \mu \mathrm{M}$ strychnine, a blocker of glycine-mediated inhibition; they were not consistently blocked by $100 \mu \mathrm{M}$ bicuculline or by $100 \mu \mathrm{M}$ picrotoxin, blockers of GABA-mediated inhibition. These results indicate that the inhibition is likely to be mediated by glycine.

A simple interpretation of the finding that IPSPs have latencies (1.2-4 msec) at least $2 \times$ as long as EPSPs (0.6-0.9 msec) is that cells in the VCN are excited monosynaptically by auditory nerve fibers, and that they are inhibited disynaptically through interneurons within the VCN. To test physiologically whether EPSPs and IPSPs are, respectively, monosynaptic and polysynaptic, 500-700 $\mu \mathrm{M}$ sodium pentobarbital was applied to the preparation. Pentobarbital raised the thresholds of all impaled cells and their synaptic inputs. FPSPs could be evoked in the presence of pentobarbital by raising the stimulus strength, as expected when thresholds are raised in a monosynaptic circuit; even if the thresholds of IPSPs were lower than those of EPSPs in normal saline, they were raised above those of EPSPs in the presence of pentobarbital. The finding that the thresholds of IPSPs are raised more than those of EPSPs supports the interpretation that IPSPs are mediated through a polysynaptic

\footnotetext{
Received Nov. 15, 1985; revised Feb. 24, 1986; accepted Feb. 26, 1986.

We received much help from colleagues, for which we are indeed grateful. Jo Ann Eckleberry, Joan Meister, Inge Siggelkow, Paul Luther, and Harry Ludwig provided technical help; Carol Dizack and Terrill Stewart helped to prepare illustrations; Robert Klipstein and Holly Jackson provided office help. We thank Judith Hirsch, Robert Wickesberg, Philip Smith, William Rhode, Deric Bownds, and Vijay Baichwal for reading and criticizing our manuscript. We owe special thanks to Judith Hirsch who made critical contributions throughout. This work was supported by NIH Grants NS 17590 and NS 12732.

Correspondence should be addressed to Donata Oertel, Department of Neurophysiology, University of Wisconsin, 281 Medical Sciences Building, Madison, WI 53706.
}

Copyright @ 1986 Society for Neuroscience $0270-6474 / 86 / 092691-16 \$ 02.00 / 0$ pathway, and this may explain why inhibition has been detected inconsistently in vivo.

It has been clear since the earliest recordings were made from the ventral cochlear nuclei (VCN) that all of the larger cells are excited by pure tones. There is only a small amount of evidence from in vivo physiological studies that inhibitory circuitry plays any role in the VCN. Efferent inputs may be inhibitory or excitatory (Comis, 1970; Comis and Whitfield, 1968). Evans and Nelson (1973) reported that some cells in the VCN had inhibitory sidebands. Brownell (1975) showed with recordings from axons in the trapezoid body that the bushy cells that correspond to globular cells in Nissl-stained tissue (Brawer et al., 1974; Osen, 1969) have inhibitory sidebands. Martin and Dickson (1983) have reported that firing of cells that are pharmacologically excited can be suppressd by tones that are higher than the characteristic frequency. In the recordings we have made from the principal cells of the VCN in vitro, the inhibition, as well as the excitation, evoked by activity in auditory nerve fibers is robust and prominent (Oertel, 1983; Wu and Oertel, 1984). Intracellular recordings from cells in brain slice preparations of the VCN show that 2 types of cells can be distinguished on the basis of their responses to polarization with current. Cells with type I properties fire large, regular action potentials when they are depolarized with current; cells with type II properties fire 1 or 2 small action potentials, and they show strong rectification when they are depolarized with current (Oertel, 1983). That type I and type II properties belong to the 2 principal morphological cell types, stellate and bushy cells, respectively, was shown by injecting HRP into cells whose properties were recorded (Wu and Oertel, 1984). Both excitatory and inhibitory synaptic responses were recorded from identified stellate cells and identified bushy cells (Wu and Oertel, 1984).

It is unlikely that the organization of the cochlear nuclei of mice, in which the intracellular recordings were made in vitro, is different from that of the cat, in which responses to tones have been recorded from single cells. The same major cell types can be distinguished in each. Globular and spherical cells in Nissl-stained tissue correspond to the bushy cells in Golgi- or HRP-labeled cells; multipolar cells correspond to stellate cells in Golgi-stained material (Brawer et al., 1974; Webster and Trune, 1982; Willard and Ryugo, 1983; Wu and Oertel, 1984). Furthermore, it has been shown in the cat that bushy cells, many stellate cells, and octopus cells are contacted not only by terminals of auditory nerve fibers, but also by terminals containing flattened vesicles whose origin is unknown (Cant, 1981; Cant and Morest, 1979b; Kane, 1973; Tolbert and Morest, 1982b).

In the spinal cord, glycine uptake has been associated with terminals containing flattened vesicles (Matus and Dennison, 1971). There is considerable biochemical evidence from a variety of mammalian species that glycine and GABA are in volved in the circuitry of the VCN (Adams and Mugnaini, 1984; Caspary et al., 1979; Godfrey et al., 1977, 1978; Martin et al., 1982; 
Moore and Moore, 1984; Schwartz, 1983; Wenthold, 1979).

Most physiological recordings from single cells have described the responses to pure tones in anesthetized animals. Cells in the VCN respond to tones with several characteristic temporal firing patterns that involve excitation of postsynaptic cells by auditory nerve fibers (Godfrey et al., 1975; Kane, 1973; Kiang et al., 1973; Pfeiffer, 1966; Rhode et al., 1983). Our experiments show that inhibition is mediated, at least in part, by a different group of auditory nerve fibers, not necessarily of a different type, than the one that mediates excitation. What the relationship is between the sound frequencies to which these different auditory nerve fibers respond is impossible to say from our experiments. It is likely, however, that neuronal inhibition will be involved in the analysis of spectrally complex sounds, rather than pure tones. We will show that the inhibitory circuitry in the VCN is probably mediated by interneurons intrinsic to the VCN, that the inhibition is probably glycinergic and specifically blocked by $1 \mu \mathrm{M}$ strychnine. The inhibition is attenuated in the presence of barbiturate anesthetics.

\section{Materials and Methods}

\section{Brain slice preparation}

The preparation of brain slices of the VCN has been described previously (Oertel, 1983, 1985). Albino mice of the strain NFS were used in early experiments, pigmented mice of the strain BTBR in later experiments. The results were identical in the 2 strains. Mice between 14 and $29 \mathrm{~d}$ old were used in these experiments. The preparations consisted of the most lateral parasagittal section of the brain stem, about $250 \mu \mathrm{M}$ thick, containing the auditory nerve root and the lateral parts of the VCN. The slices were maintained in a chamber $(0.3 \mathrm{ml})$ through which oxygenated saline at $35^{\circ} \mathrm{C}$ was continually perfused both over and under the slice at about $10 \mathrm{ml} / \mathrm{min}$ (Oertel, 1985).

\section{Saline composition}

The composition of the saline was $124 \mathrm{mM} \mathrm{NaCl}, 5 \mathrm{mM} \mathrm{KCl}, 1.2 \mathrm{mM}$ $\mathrm{KH}_{2} \mathrm{PO}_{4}, 2.4 \mathrm{mM} \mathrm{CaCl}_{2}, 1.3 \mathrm{mM} \mathrm{MgSO}_{4}, 26 \mathrm{~mm} \mathrm{NaHCO}$ and $10 \mathrm{~mm}$ glucose, saturated with $95 \% \mathrm{O}_{2}, 5 \% \mathrm{CO}_{2}, \mathrm{pH} 7.4$. GABA, glycine, picrotoxin, (-)bicuculline methiodide (Sigma), strychnine sulfate, or sodium pentobarbital were added to the normal saline at concentrations indicated in the text. At concentrations of $10 \mathrm{~mm}, \mathrm{GABA}$ and glycine were substituted for $\mathrm{NaCl}$. The chloride concentration was varied in some experiments by substituting isethionate for chloride. The potassium concentration was varied by substituting with sodium.

\section{Electrophysiology}

Except when otherwise noted, electrodes were filled with $4 \mathrm{~m}$ potassium acetate (KAc) and had resistances of between 100 and $200 \mathrm{M} \Omega$. After backfilling, they were dipped in a $2 \%$ solution of dichlorodimethyl silane in carbon tetrachloride. Standard techniques were used to make intracellular recordings. The stump of the auditory nerve was stimulated through a pair of tungsten electrodes, insulated except at their ends. The electrodes were about $50 \mu \mathrm{m}$ in diameter and were separated by 50 $100 \mu \mathrm{m}$. Both tips were placed on the nerve stump. The experimental arrangement is shown diagrammatically in Figure 14. The duration of stimulating pulses was held constant at $100 \mu \mathrm{sec}$; the voltage could be varied between 0 and $100 \mathrm{~V}$. The voltages required to elicit synaptic responses usually lay between 1 and $30 \mathrm{~V}$.

\section{Technical considerations}

Because large fibers are excited at lower thresholds than small fibers, most and perhaps all synaptic responses to stimulation of the nerve probably result from the activation of the large afferent fibers that receive input from inner hair cells. The large afferent fibers constitute $79 \%$ of the total number of fibers in the mouse (Ehret, 1979), and in the cat their diameters are between 6 and $10 \times$ larger than those of the smaller afferent fibers that innervate the outer hair cells (Arneson and Osen, 1978; Liberman, 1980). Occasionally, when the nerve stump was cut unusually short and when the stimulating electrodes were placed very near, or in, the cochlear nuclei, the cells that were impaled could be driven directly, that is, cells responded with an action potential that followed the stimulus artifact with no synaptic delay. Such responses were insensitive to the removal of extracellular $\mathrm{Ca}^{2+}$. In such cells, synaptic responses were either absent or obscured by the action potentials. From results such as these we conclude that, generally, electrical stimulation excites only fibers in the auditory nerve.

The accuracy of the measurements of resting potential varied among cells. In all experiments, chart records monitored the resting potential at all times; all experimental manipulations were also monitored on the chart. If the electrode potential returned to its original level when the electrode came out of the cell, the resting potential could be determined at all times of the experiment. Sometimes, however, there was a difference in the zero level before and after the recording, either because of a change in the tip potential or as a result of drift during long recordings (which lasted as long as $6 \frac{1 / 2}{\mathrm{hr}}$ ), making an accurate measurement of the resting potential impossible. Most measurements were accurate to within $5 \mathrm{mV}$. Occasionally the uncertainty was as high as $10 \mathrm{mV}$.

\section{Anatomical considerations}

In the cat, only a few bushy cells lie caudal to the nerve root, so the nerve root can be used to define the border between regions that are cytologically fairly distinct: the anteroventral cochlear nucleus (AVCN) and the posteroventral cochlear nucleus (PVCN) (Osen, 1969, 1970; Tolbert and Morest, 1982a; Tolbert et al., 1982). In mice, however, bushy and stellate cells, indistinguishable anatomically or physiologically from those anterior to the nerve root, occupy the lateral regions of the cochlear nuclear complex posterior to the nerve root (Willard and Ryugo, 1983; Wu and Oertel, 1984). Since we cannot define a border between the AVCN and the PVCN in our preparations, we will refer to the whole region as the "VCN."

Because the brain tissue is soft, the slices vary somewhat in which cells they contain. They were selected to contain the lateral portion of the nerve root and tissue of the VCN anterior and posterior. They were also selected to be no more than $250 \mu \mathrm{m}$ thick; the VCN is more than $300 \mu \mathrm{m}$ thick, so the cut was consistently made through the cochlear nucleus. The slices, therefore, did not contain the most medial parts of the nucleus and nerve root. They consistently contained the superficial layer of granule cells that covers the most lateral parts of the VCN (Mugnaini et al., 1980a) and some globular cells, multipolar cells, and small spherical cells (Osen, 1969; Webster and Trune, 1982). We cannot say whether the slices contained the region called the "small cell cap" (Osen, 1969). Like those who have studied the anatomy of this region in mice (Mugnaini et al., 1980a; Webster and Trune, 1982), we have found the small cell cap to be difficult or impossible to distinguish in mice. Our slices do consistently contain the region dorsal to the nerve root which, in cats, contains the small cell cap. Some preparations extended far enough forward to include large spherical cells; such preparations were cut nearly parasagittally and included little tissue posterior to the nerve root. Other preparations that were cut more obliquely, anterolateral to posteromedial, containcd globular and multipolar cells, part of the octopus cell area, and the most ventral and lateral parts of the dorsal cochlear nucleus and the lamina of granule cells (Mugnaini et al., 1980a). Of a sample of 26 slice preparations of the VCN that were examined histologically, 11 contained small parts of tissue of the dorsal cochlear nucleus.

\section{Results}

We have made intracellular recordings from over 400 cells in more than 150 slice preparations of the VCN. The present study is based specifically on recordings from 120 cells. The recordings from 75 cells in 50 slices were of the highest quality; the recordings from 45 other cells were acceptable. The quality of impalements was judged by a combination of criteria. Since the properties of cells from which long (1-7 hr), stable recordings were made were consistent, they were judged to be of the highest quality. They had resting potentials between -58 and $-70 \mathrm{mV}$, their action potentials were brief and could be elicited with small currents (less than $0.2 \mathrm{nA}$ ), and their input resistances were high ( 30 to $60 \mathrm{M} \Omega$ ). Cells whose properties fulfilled some, but not all, of these criteria were judged acceptable. Recordings from cells that seemed to have smaller resting potentials were usually unstable, indicating that the impalements were not good. When cells had resting potentials larger than $-70 \mathrm{mV}$, their input resistances were low, and the morphology of cells under such 

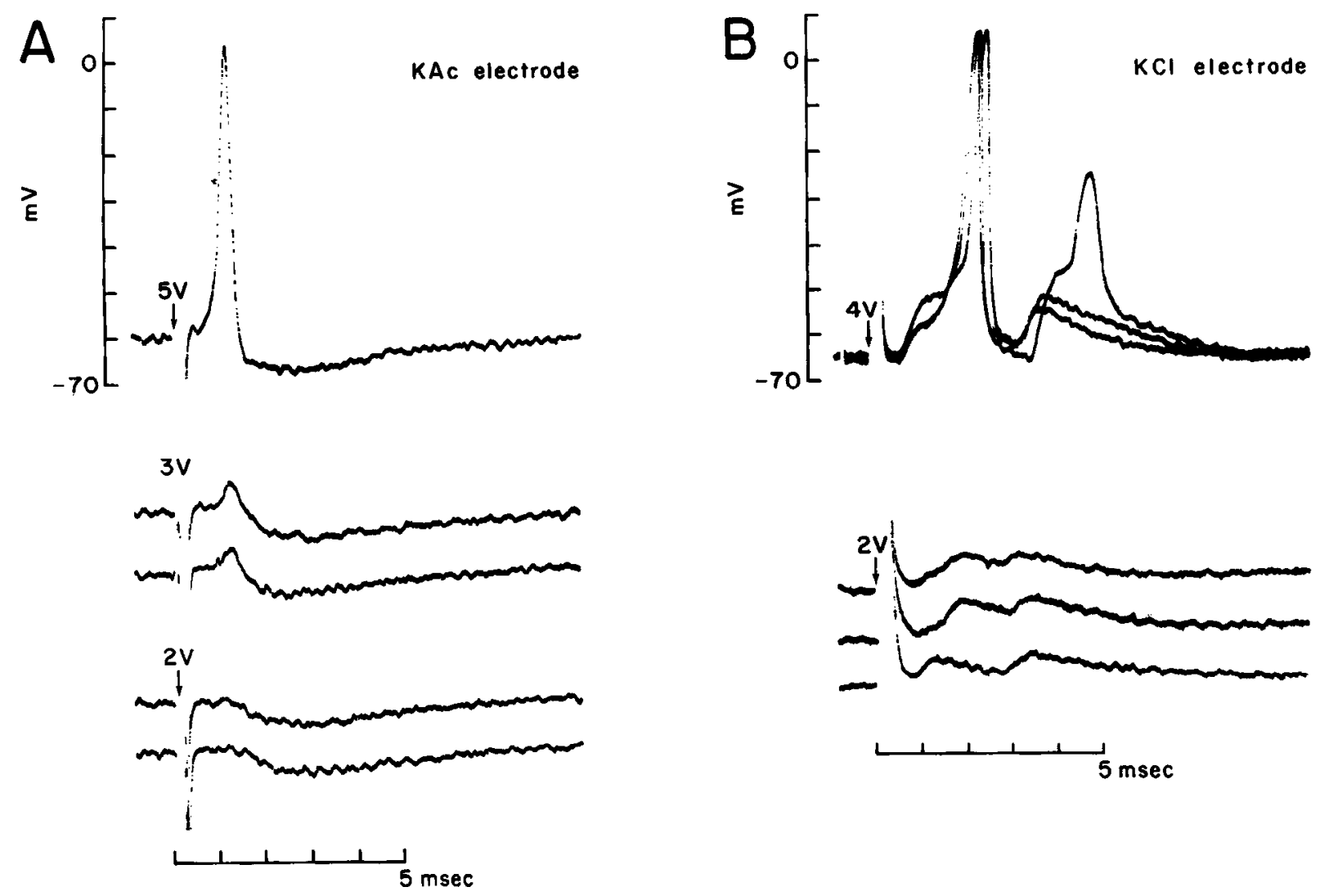

Figure 1. Synaptic responses of two cells with type I characteristics to electrical stimulation of the auditory nerve. $A$, Recording from a cell made with an electrode filled with $4 \mathrm{~m}$ KAc. Top trace. A suprathreshold response obscured underlying EPSP and IPSP. Middle traces, When the auditory nerve was stimulated with weaker pulses, subthreshold EPSPs preceded and were cut short by IPSPs. Bottom traces, Still weaker shocks to the auditory nerve elicited only IPSPs. $B$, Recording from a cell with an electrode filled with $3 \mathrm{M} \mathrm{KCl}$. Top, traces, Three superimposed traces showing depolarizing synaptic responses, the second probably being a reversed IPSP. Lower traces, Three examples of subthreshold synaptic responses. Arrows indicate the beginning of stimulation of the auditory nerve.

conditions showed that they were swollen (Oertel, 1983; Wu and Oertel, 1984). These cells were unacceptable.

\section{IPSP}

Almost all cells from which recordings were made in the VCN responded to electrical stimulation of the auditory nerve with a short-latency EPSP and a longer-latency IPSP. Inhibitory as well as excitatory synaptic responses were recorded both in cells with large, regularly firing action potentials - cells with type I characteristics, which were presumably stellate cells-and in cells that fired only 1 or 2 small action potentials when they were depolarized with a steady current pulse-cells with type II characteristics, which were presumably bushy cells (Wu and Oertel, 1983). Figure $1 A$ shows an example of such responses in a cell with type I properties. When the nerve stump was stimulated with pulses of low voltage, only IPSPs were recorded (lower traces). The duration of the IPSPs was about $5 \mathrm{msec}$, and they occurred with a synaptic delay of about $1.3 \mathrm{msec}$. At slightly higher stimulus strengths, early EPSPs were recorded in addition to the later IPSPs (middle traces). At still higher stimulus strengths, the EPSPs could become suprathreshold and elicited an action potential whose undershoot obscured underlying IPSPs (upper trace). The observation that the thresholds for EPSPs and IPSPs were different is consistent with the interpretation that they are mediated by different auditory nerve fibers. The latencies of the EPSPs are between 0.6 and $0.9 \mathrm{msec}$, while the latencies of IPSPs are between 1.2 and $4 \mathrm{msec}$, suggesting that the IPSPs may be mediated by a disynaptic pathway through inhibitory interneurons intrinsic to the slice preparation.
In some preparations the size of IPSPs increased in a few discrete steps as a function of stimulating voltage. Rarely, we recorded two IPSPs that occurred at different times after stimulation of the auditory nerve (one example is shown in Fig. $3 B$ ). These observations were consistent with IPSPs' being mediated by relatively few interneurons.

Often IPSPs can be elicited with weaker stimulation of the auditory nerve than EPSPs. In the sample of 75 very good recordings, IPSPs clearly had lower thresholds at one or the other stimulus polarity in 44 cells. Whether or not there is a consistent difference in thresholds of EPSPs and IPSPs is not clear. Our experiments had sampling biases; we generally stimulated the nerve with electrodes that abutted the nerve laterally and we generally recorded from the postsynaptic cells that lay most laterally in the VCN.

Table 1. Reversal potentials of IPSPs

\begin{tabular}{llll} 
Cell type & No. of cells & $\begin{array}{l}\text { Mean rev. pot. } \\
(\mathrm{mV})\end{array}$ & $\begin{array}{l} \pm \mathrm{SD} \\
(\mathrm{mV})\end{array}$ \\
\hline I & 12 & -68 & \pm 5 \\
II & 9 & -65 & \pm 2 \\
$\quad$ Total & 21 & -67 & \pm 4
\end{tabular}

Summary of measurements of reversal potentials of IPSPs obtained from records such as those shown in Figures 2 and 3. 


\section{Type I cell}

Normal

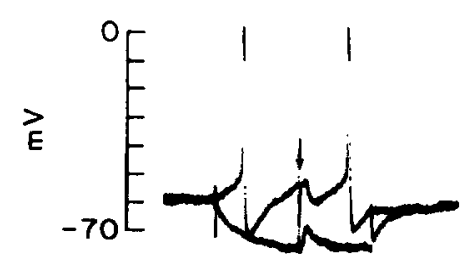

$\varliminf_{-0.5}^{0.5}[-]$

$50 \% \mathrm{Cl}$
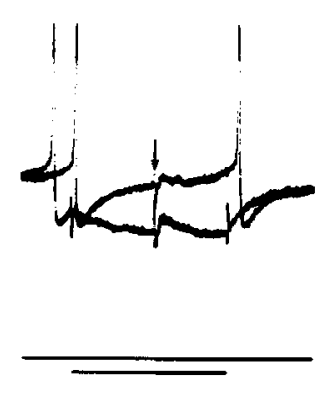

Type II cell

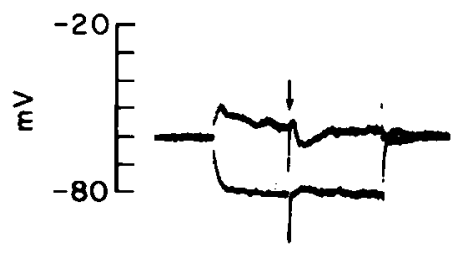

${ }_{-0.5}^{0.5}\left[-\frac{1+1 / 10 \mathrm{msec}}{\underbrace{1+1}_{0}}\right.$
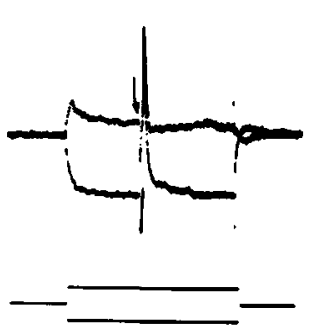

Normal
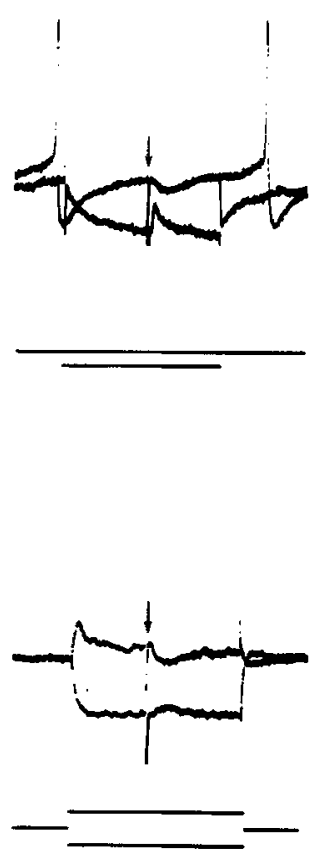

Figure 2. Dependence of the reversal potential of IPSPs on the extracellular $\mathrm{Cl}^{-}$concentration. Artifacts under the arrows indicate when the auditory nerve was stimulated electrically. Each panel shows 2 superimposed traces in which the responses to stimulation of the nerve are recorded while the cell is polarized to different levels with intracellular injection of current. Upper 3 panels show recordings from a cell with type I properties, which fire a few spontaneous action potentials. Lower 3 panels show recordings from a cell with type II properties. Left panels show that the IPSPs reversed slightly below the resting potential in normal saline, which contained $134 \mathrm{~mm} \mathrm{Cl}^{-}$, in type I and type II cells. Middle panels show that the reversal potentials of IPSPs become more positive than $-60 \mathrm{mV}$ in saline containing only $67 \mathrm{~mm} \mathrm{Cl}^{-}$. Reversal potentials are impossible to measure precisely because they are more positive than the firing thresholds of the cells. Right panels show that the reversal potentials return to their original levels after normal saline is reintroduced. Note that the reversal potential of the IPSPs in the type I cell are higher than the undershoots of the action potentials.

\section{Ionic basis of IPSP}

The reversal potentials of IPSPs are consistently near the resting potentials of both type I and type II cells. In 21 cells, the reversal potentials were measured to be $-67 \pm 4 \mathrm{mV}$ (mean \pm SD) (Table 1). There was no difference between reversal potentials in type I and type II cells. Since reversal potentials of IPSPs lay near the resting potential, the equilibrium potential for $\mathrm{Cl}^{-}$, the IPSPs might be generated by an increase in $\mathrm{Cl}^{-}$permeability.

When cells were impaled with electrodes filled with $3 \mathrm{M} \mathrm{KCl}$, hyperpolarizing IPSPs were not recorded. Figure $1 B$ shows the synaptic responses of a cell with type I properties, recorded with a KCl-filled electrode. The synaptic responses consisted of 2 depolarizing responses, both of which could be suprathreshold. Presumably, leakage from the electrode raised the intracellular $\mathrm{Cl}^{-}$concentration, raising the cquilibrium potential for $\mathrm{Cl}^{-}$to a more depolarized level.

Experiments testing the dependence of the reversal potentials of the IPSPs in type I and type II cells on the extracellular $\mathrm{Cl}^{-}$ concentration are illustrated in Figure 2. The top traces are from a type I cell, the bottom traces are from a type II cell. Each set of traces measures the response of the auditory nerve to electrical stimulation (arrows) while the cell is polarized with current. The traces at the left show that, in normal saline, IPSPs reversed slightly below the resting potentials; in the type I cell the reversal potential lay between about -61 and $-69 \mathrm{mV}$, and in the type II cell between -63 and $-78 \mathrm{mV}$. The reversal potential of the
IPSP recorded in the type I cell lay above the lowest part of the undershoots. When the extracellular $\mathrm{Cl}^{-}$concentration was lowered, the reversal potentials were raised above the resting potentials in both cells (middle traces) and returned to their original levels when normal saline was reintroduced (right traces). In the type II cell, the depolarization caused by the IPSP in the presence of reduced extracellular $\mathrm{Cl}^{-}$became depolarizing and suprathreshold and caused the cell to fire action potentials.

In $4 / 4$ experiments, changes in the extracellular $\mathrm{K}^{+}$concentration did not affect the reversal potential of IPSPs. The experiments illustrated in Figure 3 show traces from 2 of those experiments. Each set of traces shows inhibitory synaptic responses to electrical stimulation of the auditory nerve (arrows) recorded while the cell was polarized with current. Figure $3 A$ shows responses of a type $\mathrm{I}$ cell. When the $\mathrm{K}^{+}$concentration was lowered from the normal $6.2 \mathrm{~mm}$ to $2 \mathrm{mM}$, the reversal potential of the IPSP remained at about $-68 \mathrm{mV}$. Figure $3 B$ shows the results of a similar experiment in a type II cell. The IPSP in this cell had 2 components, the larger component occurring later than the smaller component. Both components reversed at between -65 and $-75 \mathrm{mV}$, independent of the extracellular $\mathrm{K}^{+}$concentration. This cell hyperpolarized by 1 or $2 \mathrm{mV}$ when the $\mathrm{K}^{+}$concentration was lowered; an increase in the height of the action potential accompanied the hyperpolarization. When the $\mathrm{K}^{+}$concentration was raised to $12 \mathrm{mM}$, the cell depolarized by $4 \mathrm{mV}$ and the action potential became smaller. 
A. Type I
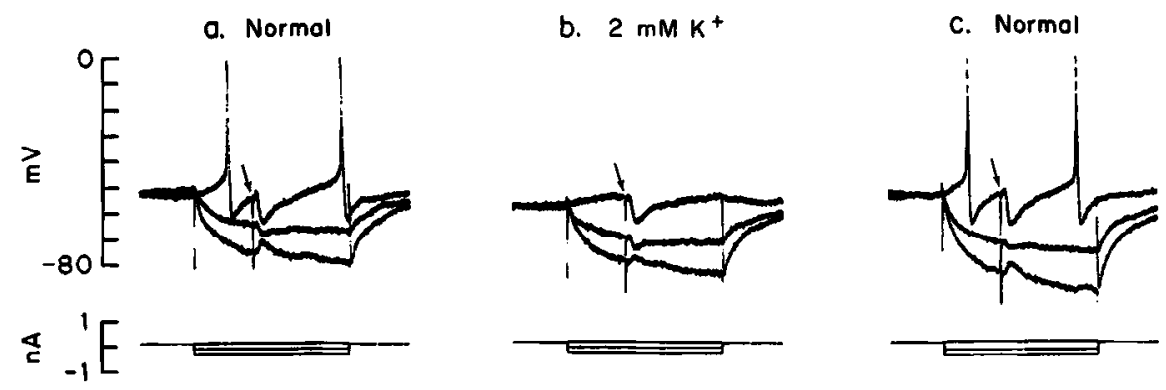

B. Type II

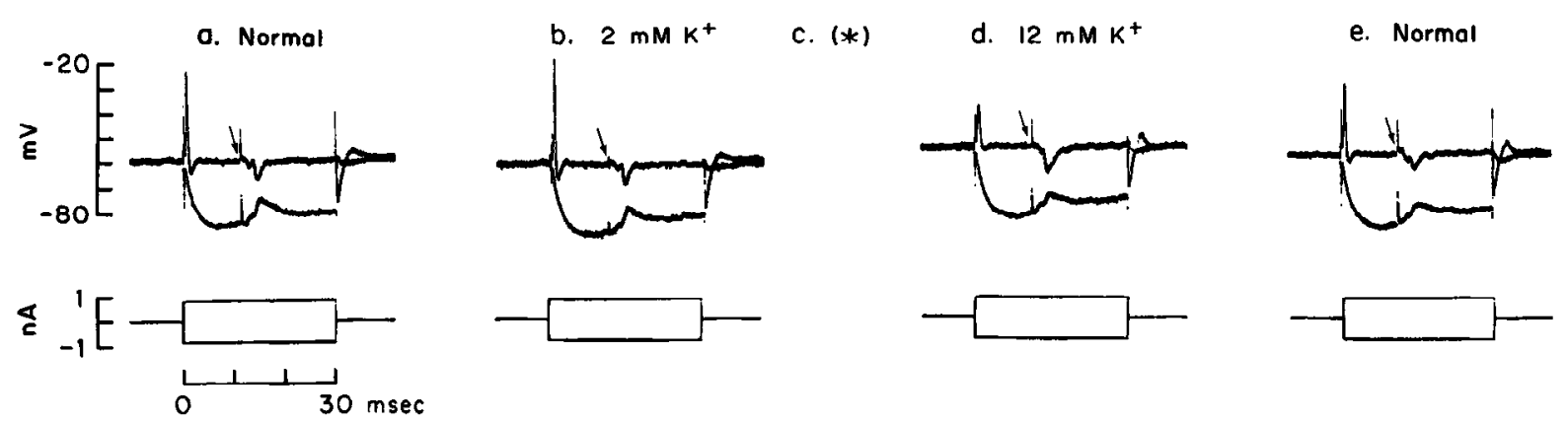

Figure 3. Changes in the extracellular $\mathrm{K}^{+}$concentration do not affect the reversal potential of IPSPs. A: $a$, Three superimposed traces showing the synaptic response to electrical stimulation of the auditory nerve (arrow), while a type I cell was polarized with various amounts of current in normal saline containing $6.2 \mathrm{mM} \mathrm{K}^{+}$. The IPSP reverses at about $-68 \mathrm{mV}$. $b$, When the extracellular $\mathrm{K}^{+}$concentration was lowered to $2 \mathrm{~mm}$, the cell hyperpolarized by $4 \mathrm{mV}$ but the reversal potential remained at about $-68 \mathrm{mV}$. $c$, The effect of extracellular $\mathrm{K}^{+}$concentration on the resting potential was reversible. (The tops of the action potentials were cut off by the oscilloscope screen.) $B: a$, Two superimposed traces showing the reversal of a double IPSP in a type II cell. In normal saline, containing $6.2 \mathrm{~mm} \mathrm{~K} \mathrm{~K}^{+}$, the reversal potential was between -65 and $-75 \mathrm{mV}$. $b$, When the extracellular $\mathrm{K}^{+}$concentration was lowered to $2 \mathrm{~mm}$, the cell hyperpolarized $2 \mathrm{mV}$ and fired a larger action potential, but the reversal potential of the IPSPs remained unchanged. $c$, Normal saline was returned to the bath; traces not shown. $d$, When the extracellular $\mathrm{K}^{+}$concentration was raised to $12 \mathrm{mM}$, the cell depolarized by $4 \mathrm{mV}$, causing the action potential to be attenuated, but the reversal potential of the IPSPs remained unchanged. $e$, Changes in the resting potential were reversible. Reversal potential of IPSPs remained unchanged.

a. Normol

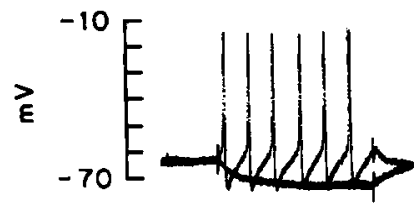

$\stackrel{\square}{0.5} \mathrm{E}=$ b. Normal
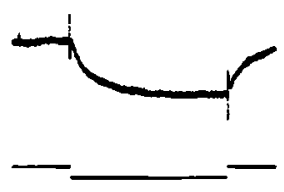

f. $10 \mathrm{mM} \mathrm{GABA}$

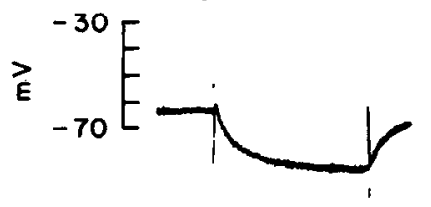

$\stackrel{0.5}{E-0.5} \mathrm{E}-\frac{}{\underbrace{1+1}_{0}}-$
C. $10 \mathrm{mM}$ glycine
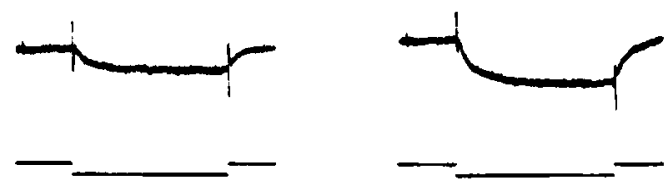

Figure 4. Sensitivity of a type I cell to glycine and GABA. $a$, Responses to pulses of depolarizing and hyperpolarizing current identify the cell as type $I$. $b-g$. Sequentially recorded responses to pulses of hyperpolarizing current, measuring the input resistance of the cell as it was challenged with the putative neurotransmitters, glycine and GABA, dissolved in the bathing saline. The input resistance dropped reversibly in the presence of both glycine and GABA. This cell, like most others, was more sensitive to GABA than to glycine. 


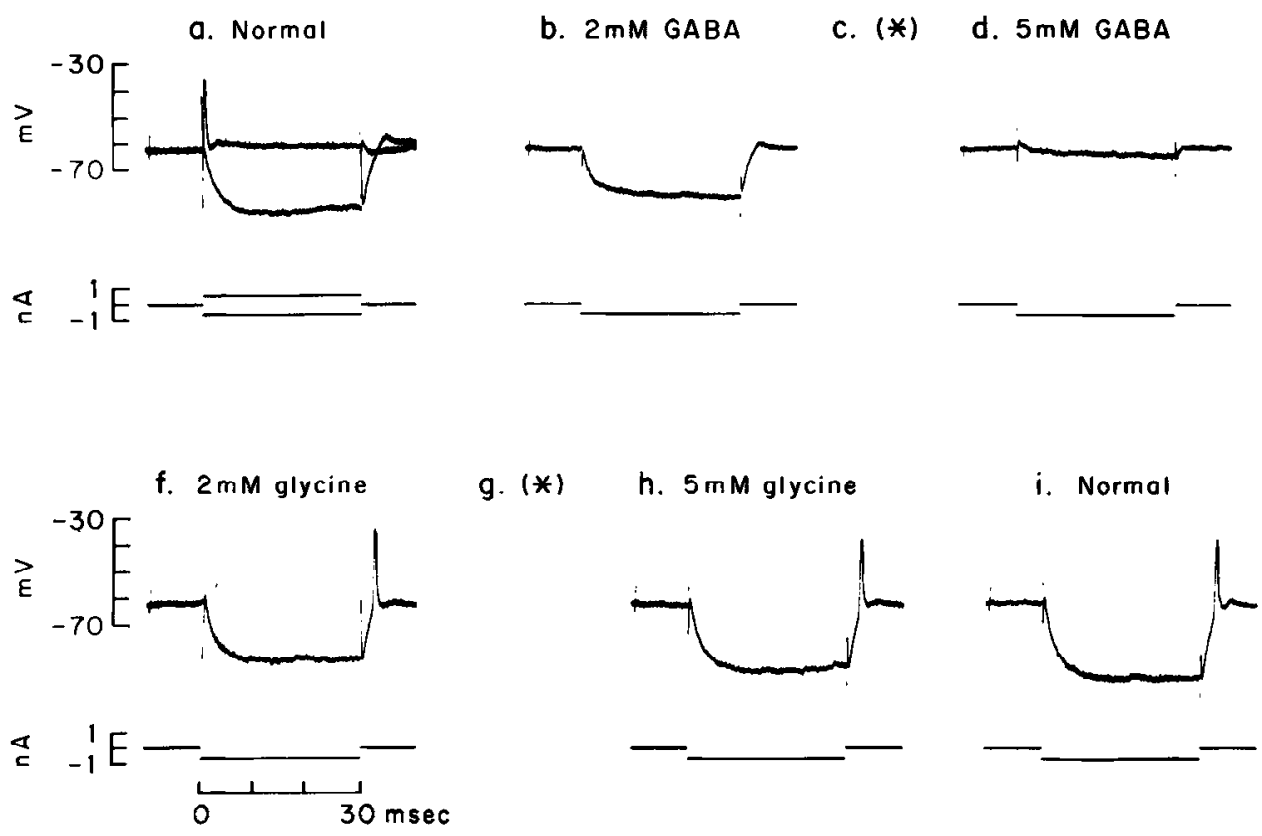

Figure 5. Sensitivity of a type II cell to GABA and glycine. $a$, Pair of traces showing responses to depolarizing and hyperpolarizing current identify the cell as type II. $b-i$. Sequential responses to intracellularly injected pulses of hyperpolarizing current. Input resistance of the cell dropped in a graded way as a function of concentration of applied GABA. This cell was sensitive to $2 \mathrm{~mm}$ glycine but insensitive to $5 \mathrm{~mm}$ glycine applied later. This is an example of desensitization. Between test applications, normal saline was returned to the bath; where the actual traces are not shown, the return to normal saline is indicated by an asterisk.

Had the IPSPs been mediated by increases in $\mathrm{K}^{+}$conductance, changes in extracellular $\mathrm{K}^{+}$concentration from 6.2 to $2 \mathrm{mM}$ would have lowered the reversal potential by $28 \mathrm{mV}$; changes in the extracellular $\mathrm{K}^{+}$concentration from 6.2 to $12 \mathrm{mM}$ would have raised the reversal potential by $17 \mathrm{mV}$. The finding that no change in the reversal potential was observed shows that IPSPs are not mediated by changes in $\mathrm{K}^{+}$conductance. This evidence that the IPSPs are sensitive to manipulations of the intracellular and extracellular $\mathrm{Cl}^{-}$concentration but not to manipulations of the extracellular $\mathrm{K}^{+}$concentration strongly suggests that the IPSPs are generated by an increase in $\mathrm{Cl}^{-}$permeability.

\section{Sensitivity to $G A B A$ and glycine}

The sensitivity of cells in the VCN to GABA and glycine was measured by monitoring the input resistance of cells while GABA and glycine were applied in the bath at concentrations between 0.1 and $10 \mathrm{~mm}$. Figure 4 shows traces recorded sequentially from a single cell. The pair of superimposed traces in Figure $4 a$ identifies the cell as type I, presumably a stellate cell. It fired large, regular action potentials and, at the end of the depolarizing and hyperpolarizing current pulses, the return to rest of the membrane potential occurred at similar rates. In the presence of $10 \mathrm{~mm}$ glycine (Fig. $4 \mathrm{c}$ ), the time constant and the magnitude of the hyperpolarization were decreased reversibly, indicating that the input resistance of the cell dropped in the presence of glycitıe. The traces in Figure $4, e, f$ show a reversible change in input resistance in the same cell in the presence of $10 \mathrm{mM}$ GABA.

Sequential recordings from a second cell are shown in Figure 5 . Figure $5 a$ shows responses to intracellularly injected current pulses of equal magnitude and opposite polarity. Depolarizing current elicited only a single action potential, and the voltage change elicited by the current was thereafter small compared to that elicited by hyperpolarizing current; these responses identify the cell as type II, presumably a bushy cell. The input resistance was lowered reversibly and in a graded way when GABA was applied at various concentrations. The cell was insensitive to glycine at concentrations less than $5 \mathrm{~mm}$.

Figures 4 and 5 illustrate several features that were encountered consistently. Cells were generally more sensitive to GABA than to glycine. At high concentrations of GABA and glycine, the changes in input resistance were so large that they were impossible to measure (Figs. $4 f, 5 d$ ).

From experiments such as those illustrated above, dose-response curves were made in which input conductance, calculated as the inverse of input resistance, was plotted as a function of concentration. The points where input resistance was not measurable were indicated as maximal responses without units. Figure 6 shows that type I cells were sensitive both to GABA and to glycine. Usually no change in input conductance was detectable at low concentrations. With application of slightly higher concentrations, the input conductance rose precipitously. Figure 7 shows that type II cells were also sensitive both to GABA and to glycine. As with type I cells, there was considerable variability in sensitivity, with some cells showing changes in input conductance at concentrations as low as $0.1 \mathrm{~mm}$ and others responding only to concentrations of $2 \mathrm{~mm}$ or higher. Sensitivity of cells to GABA and glycine was not related to cell type.

Associated with the conductance increases, bath applications of GABA and glycine usually caused cells to hyperpolarize transiently by a fcw millivolts. The chart records in Figure 8 are from 2 cells with type I properties. The upper records are from a cell impaled with a KAc-filled electrode. Small hyperpolarizing current pulses, such as those applied in the experiments illustrated in Figures 4 and 5, were applied to monitor the changes in input resistance. Application of $1 \mathrm{~mm}$ GABA caused a small change in input resistance and a small hyperpolarization; $5 \mathrm{mM}$ glycine also caused a small transient hyperpolarization which changed to a small depolarization while the cell's input resistance dropped to an immeasurable level. The type I cell whose records are shown at the bottom of Figure 8 was impaled with a KCl-filled microelectrode. Application of GABA or glycine to 

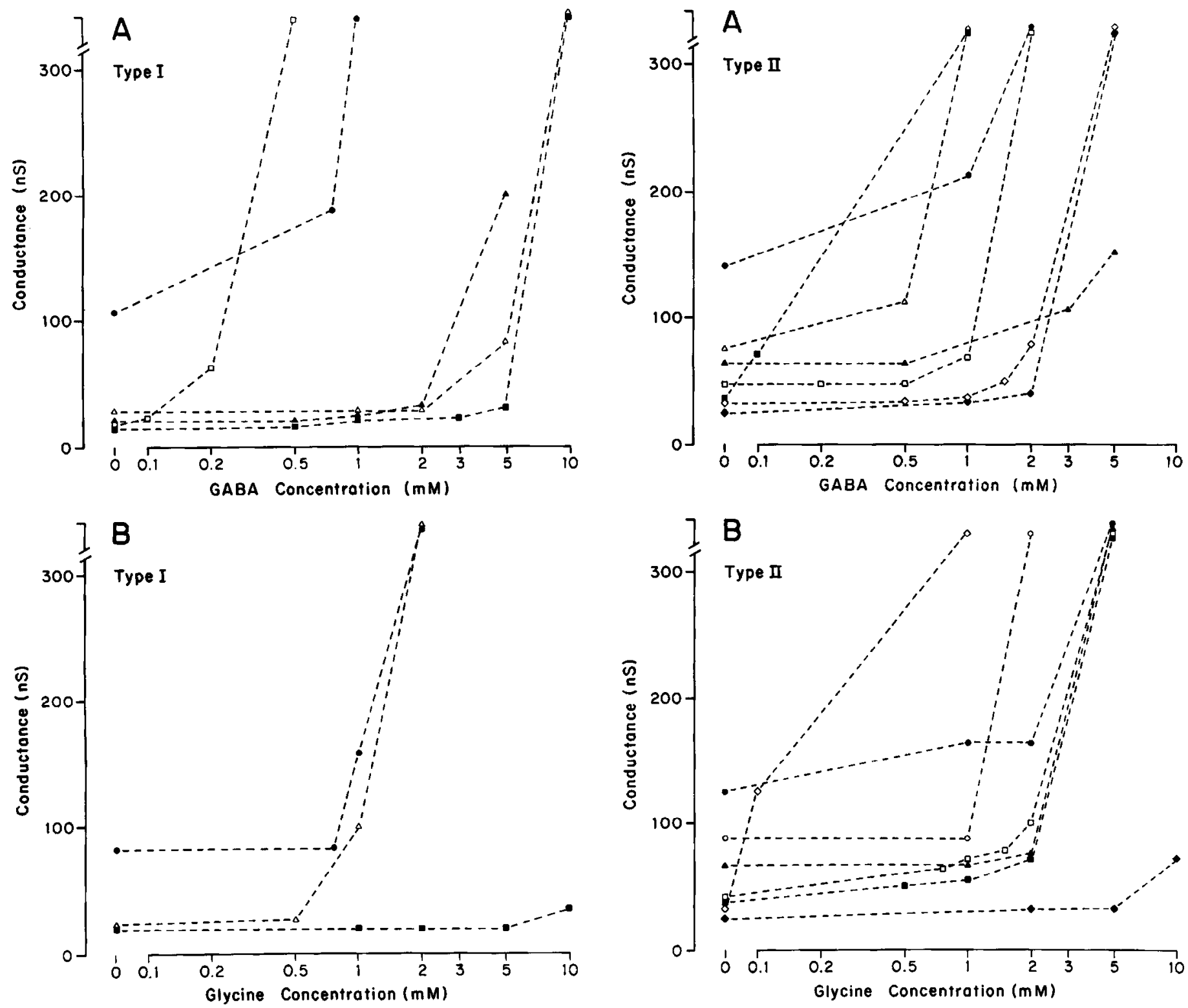

Figure 6. Dose-response curves of type I cells to bath-applied GABA and glycine. $A$, Conductance changes of type I cells, plotted as the inverse of input resistance, to GABA concentration. $B$, Conductance changes of type I cells to glycine.

the bath resulted in a large, suprathreshold depolarization. When the cell was impaled with a $\mathrm{KCl}$-filled electrode, the intracellular $\mathrm{Cl}^{-}$concentration was presumably increased, raising the equilibrium potential of $\mathrm{Cl}^{-}$above the firing threshold of the cell. The findings show that the changes in input resistance caused by bath application of GABA and glycine were the result of changes in the chloride conductance.

Since cells in the VCN are sensitive to GABA and glycine, and since, like the IPSPs, GABA and glycine cause an increase in the $\mathrm{Cl}^{-}$conductance in both type I and type II cells, either glycine or GABA could mediate the IPSPs elicited by electrical stimulation of the auditory nerve.

\section{Antagonists of IPSPS}

The sensitivity of IPSPs to picrotoxin, bicuculline, and strychnine-blockers of GABA and glycine-was tested. We found that the IPSPs were not blocked by the GABA blockers, picro-

Figure 7. Dose-response curves of type II cells to bath-applied GABA and glycine. $A$, Conductance changes of type II cells, plotted as the inverse of input resistance, to GABA concentration. $B$, Conductance changes of type II cells to glycine.

toxin and bicuculline, but they were always blocked by strychnine, even at micromolar concentrations. Figure 9 portrays an example of such a test. To show the IPSP clearly, the cell was depolarized slightly with intracellularly injected current. The IPSP recorded in normal saline was unaffected by the application of $10^{-4} \mathrm{M}$ bicuculline or $10^{-4} \mathrm{M}$ picrotoxin in the bath. However, it was completely and reversibly abolished by the application of $10^{-6} \mathrm{M}$ strychnine. It took $30 \mathrm{~min}$ to wash out the strychnine and reverse its effect.

Table 2 summarizes the results of this series of experiments. A few of the IPSPs tested seemed to be blocked by picrotoxin $(4 / 20)$ and by bicuculline (1/10). Every IPSP tested $(23 / 23)$ was completely abolished by bath application of strychnine at $10^{-6} \mathrm{M}$.

It was shown above that when a cell was impaled with a $\mathrm{KCl}$ filled microelectrode, chloride leakage into the cell seemed to raise the equilibrium potential of $\mathrm{Cl}^{-}$, causing IPSPs to reverse (Fig. $1 B$ ). If this was the case, and if strychnine blocked the 
KAC electrode
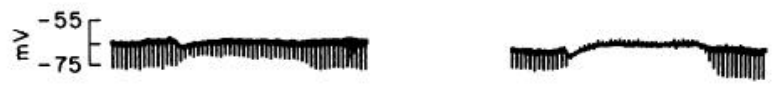

$1 \mathrm{mM}$ GABA

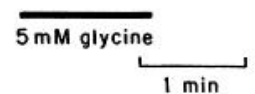

$\mathrm{KCl}$ electrode

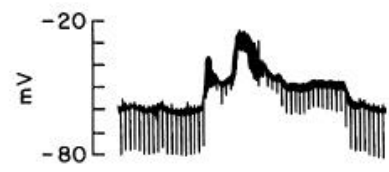

$1 \mathrm{mM}$ GABA

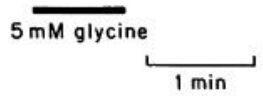

Figure $8 . \mathrm{Cl}^{-}$dependence of sensitivity to GABA and glycine. Solid bars indicate when drugs were applied. It took 20 to $30 \mathrm{sec}$ for the solutions to reach the preparation from the time the switch was turned. Upper traces, Responses of a type I cell to applications of GABA and glycine when the recording was made with a KAc-filled electrode. Like the experiments shown in Figures 4 and 5, hyperpolarizing current pulses $(0.4 \mathrm{nA}, 30 \mathrm{msec})$ were periodically applied to monitor input resistance. The cell hyperpolarized briefly and returned to near its original resting potential, and its input resistance was decreased by both GABA and glycine. Lower traces, Responses of another type I cell to applications of GABA and glycine when the recording was made with a $\mathrm{KCl}$-filled electrode. Under these conditions, GABA and glycine caused the cell to depolarize, as well as to lower the input resistance. Depolarization caused the cell to fire action potentials, which are attenuated by the chart-recorder.

IPSPs, then strychnine should abolish the second, but not the first, depolarizing synaptic response. Figure 10 shows that this indeed happened. The second depolarization, corresponding to the reversed IPSP, was reversibly blocked by $1 \mu \mathrm{m}$ strychnine.

Since strychnine is considered to be a blocker of glycine, we tested whether bath-applied strychnine could block the effects of bath-applied glycine. Figure 11 shows a chart record from a cell that received constant intracellular injections of hyperpo-
Table 2. Pharmacological blocking agents

\begin{tabular}{|c|c|c|c|c|}
\hline \multirow[b]{2}{*}{ Drug } & \multirow[b]{2}{*}{ Concentration } & \multicolumn{3}{|c|}{ Number of cells } \\
\hline & & Blocked & $\begin{array}{l}\text { Not } \\
\text { blocked }\end{array}$ & $\begin{array}{l}\text { Blocked/ } \\
\text { tot. }\end{array}$ \\
\hline \multirow[t]{6}{*}{ Strychnine } & $10^{-4}$ & 2 (I) & & \\
\hline & & 3 (II) & & \\
\hline & $10^{-5}$ & 1 (I) & & \\
\hline & $10^{-6}$ & 11 (I) & & \\
\hline & & 3 (II) & & \\
\hline & & $3(?)$ & & $23 / 23$ \\
\hline \multirow[t]{4}{*}{ Picrotoxin } & $10^{-4}$ & $2(\mathrm{I})$ & $8(\mathrm{I})$ & \\
\hline & & 2 (II) & 7 (II) & \\
\hline & & & $1(?)$ & \\
\hline & & & & $4 / 20$ \\
\hline \multirow[t]{5}{*}{ Bicuculline } & $5 \times 10^{-4}$ & & $1(?)$ & \\
\hline & $10^{-4}$ & $1(\mathrm{I})$ & $5(\mathrm{I})$ & \\
\hline & & & 2 (II) & \\
\hline & $5 \times 10^{-6}$ & & 1 (II) & \\
\hline & & & & $1 / 10$ \\
\hline
\end{tabular}

Summary of the ability to block IPSPs by the blocking agents, strychnine, picrotoxin, and bicuculline, applied at various concentrations is given as the number of cells in which IPSPs were blocked and not blocked. The type of cell is specified in parentheses, with (I) being type I or stellate cells and (II) being type II or bushy cells. Occasionally the identity of cells was uncertain; these are marked with (?). All IPSPs were blocked by strychnine.

larizing current to monitor its input resistance. The application of $5 \mathrm{~mm}$ glycine caused a drop in the input resistance and a transient hyperpolarization. The simultaneous addition of strychnine caused the input resistance to return to its former level reversibly. At the same concentration, strychnine did not block the response to bath-applied GABA. Picrotoxin and bicuculline blocked the responses to GABA but not to glycine. The results of this series of experiments are summarized in Table 3.

\section{Desensitization}

In 6 out of 83 cells, sensitivity to bath-applied GABA or glycine seemed to decrease with repeated application (Table 4). One of

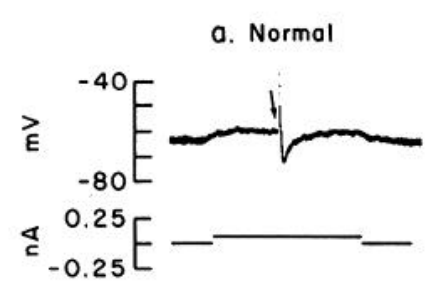

b. $10^{-4} \mathrm{M}$ bicuculline

c. Normal

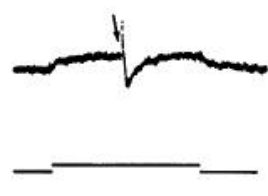

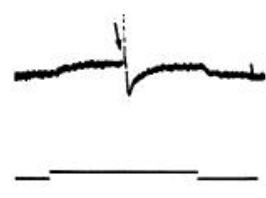

d. $10^{-4} \mathrm{M}$ picrotoxin

e. Normal

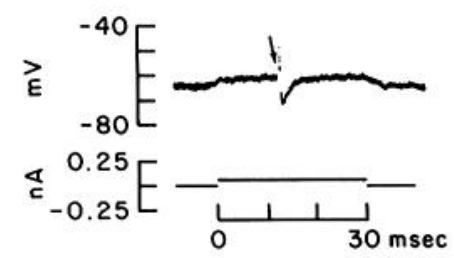

f. $10^{-6} \mathrm{M}$ strychnine
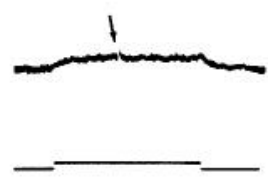

g. Normal

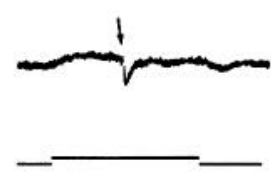

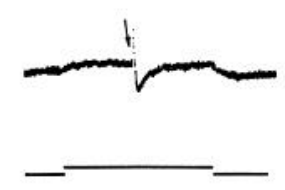

Figure 9. IPSPs are blocked by $10^{-6} \mathrm{M}$ strychnine. In each of the traces the auditory nerve was stimulated at the time indicated by the arrows and an IPSP was recorded. To resolve the IPSPs as clearly as possible, they were recorded when the cell was depolarized with current. $a-g$, Recorded sequentially; the IPSP was not blocked by bicuculline or picrotoxin and was blocked reversibly by $10^{-6} \mathrm{M}$ strychnine. 


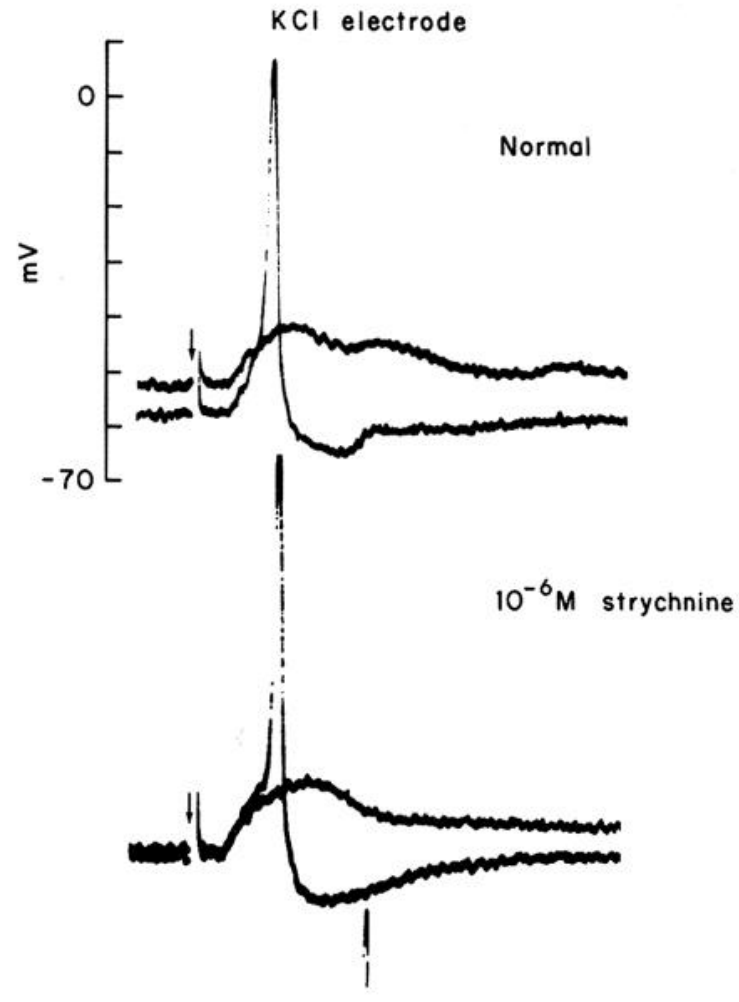

Normal

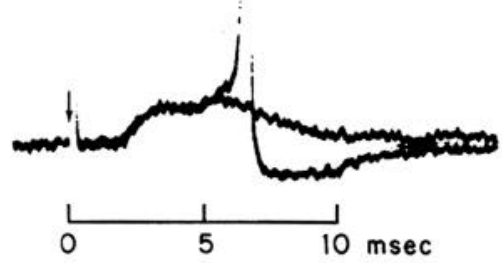

Figure 10. Reversed IPSPs are blocked with strychnine. Recording from type I cell was made with an electrode filled with $\mathrm{KCl}$. Each panel shows 2 superimposed responses. Top traces, Two depolarizing synaptic responses were recorded, one with short, the other with long latency. Middle traces, When strychnine was applied to the bath, the later synaptic response was abolished. Bottom traces, After the strychnine was washed out, the second synaptic response returned.

these cells is shown in Figure 5. This cell responded to $2 \mathrm{~mm}$ glycine with a small change in input resistance but was insensitive to $5 \mathrm{~mm}$ glycine that was applied later. Five other cells also showed desensitization. The input resistance of cells dropped in response to an initial challenge but not to later applications
Table 3. Action of bath-applied antagonists on bath-applied agonists

\begin{tabular}{llllll} 
& & & & \multicolumn{2}{r}{ Number of cells } \\
\cline { 5 - 6 } Antagonist & Conc. & Agonist & $\begin{array}{c}\text { Conc. } \\
\text { (mM) }\end{array}$ & Blocked $\begin{array}{c}\text { Not } \\
\text { blocked }\end{array}$ \\
\hline Strychnine & $10^{-6}$ & Glycine & 2 & 2 & \\
Strychnine & $5 \times 10^{-6}$ & Glycine & 5 & 1 & \\
Strychnine & $10^{-5}$ & Glycine & 10 & 3 & \\
Strychnine & $10^{-6}$ & GABA & 5 & & 1 \\
& $10^{-6}$ & GABA & 1 & & 1 \\
Strychnine & $5 \times 10^{-6}$ & GABA & 5 & & 1 \\
Picrotoxin & $10^{-4}$ & Glycine & 5 & & 1 \\
Picrotoxin & $10^{-4}$ & GABA & 2 & 1 & \\
Bicuculline & $5 \times 10^{-5}$ & GABA & 2 & 1 & \\
Bicuculline & $10^{-4}$ & GABA & 5 & 1 &
\end{tabular}

Summary of a series of experiments in which the action of the bath-applied antagonists, strychnine, picrotoxin, and bicuculline, was tested on simultaneously bath-applied agonists, GABA and glycine. One of these experiments is illustrated in Figure 11. In each case the agonist was first applied alone; then the agonist was applied in the presence of an antagonist; and finally the antagonist was removed to determine the reversibility of its action. The results show that strychnine blocks the conductance increase caused by glycine but not of GABA. Picrotoxin and bicuculline block the conductance increase caused by GABA, but picrotoxin does not block the conductance increase caused by glycine.

of similar or higher concentrations of GABA or glycine. These results are summarized in Table 4 . In all 4 of the cells tested, desensitization to GABA was accompanied by desensitization to glycine. We observed no reversals of desensitization. Observations were made for $1 \mathrm{hr}$ in 1 cell; other observations were shorter.

If the receptors that mediate the cells' responses to bathapplied putative neurotransmitters are the same as those that mediate synaptic transmission, desensitization of the receptors should cause the IPSPs to decrease in strength. In 1 of 3 cases, the IPSPs became smaller after desensitization was observed; in 2 out of 3 cases, no change was measured.

\section{Effect of pentobarbital}

Inhibition has been detected only inconsistently in the VCN in vivo, yet IPSPs are consistently present in vitro. We tested whether pentobarbital might change the effectiveness of the inhibitory circuitry, thus accounting for this difference. The results of 16 experiments showed that pentobarbital at concentrations 500 $\mu \mathrm{M}$ or more raised the firing thresholds of all cells. More current was required to depolarize cells to their firing threshold, and electrical shocks to the auditory nerve that just elicited responses in postsynaptic cells under normal conditions became subthreshold in the presence of pentobarbital. At concentrations of pentobarbital lower than $1 \mathrm{~mm}$, we observed no changes in the resting potentials or input resistances of cells. The thresholds

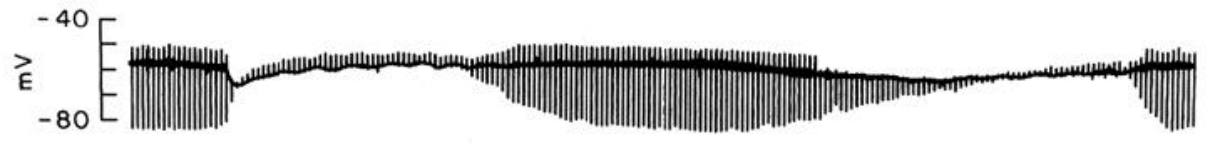

$5 \mathrm{~m} \mathrm{M}$ glycine

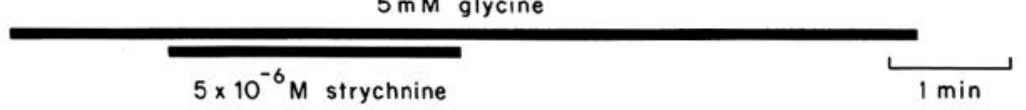

Figure 11. Strychnine can block the action of glycine. The chart record shows a cell's responses to glycine, whose application is indicated by the upper bar. Hyperpolarizing current pulses $(0.8 \mathrm{nA}, 30 \mathrm{msec})$ indicate that glycine caused the input resistance of the cell to fall. Strychnine blocked the action of glycine when applied simultaneously, causing the input resistance to return to its original level. All effects of bath applications were reversible. 
Action Potentials

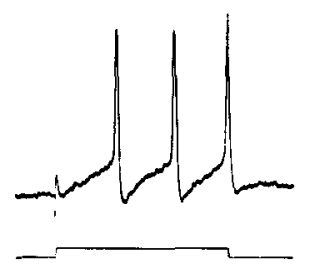

Figure 12. Barbiturate anesthetics raise firing thresholds of a type I cell and of its inputs. Top, middle, and lower rows were recorded, respectively, before, during, and after the cell was bathed in $700 \mu \mathrm{M}$ pentobarbital. Left column shows that, in the presence of pentobarbital, intracellular injection of current that normally causes the cell to fire elicits only a subthreshold depolarization. Right columns show that the firing thresholds of synaptic inputs are also raised; a $10 \mathrm{~V}$ shock to the auditory nerve elicited an IPSP in normal saline, but not when the cell was bathed in pentobarbital. The threshold of the IPSP was raised more than the threshold of the EPSP; the synaptic response with the lowest threshold was an IPSP before and after the application of pentobarbital, but during the application the synaptic response with the lowest threshold was an EPSP. Action potentials have been retouched. Resting potential of this cell could not be measured accurately either at the beginning or the end of the recording; it did not change when pentobarbital was applied.

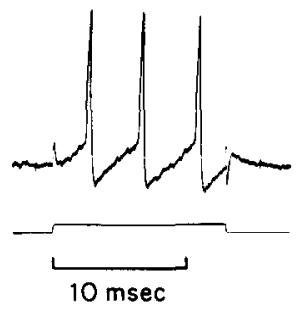

Synoptic Inputs

Normal
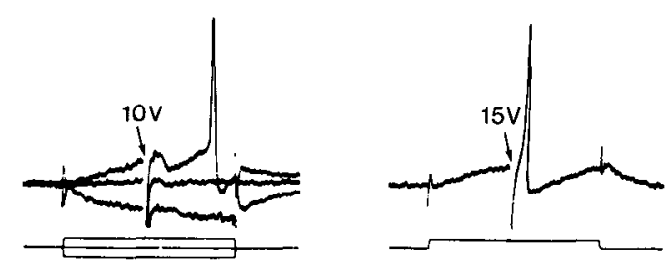

$7 \times 10^{-4} \mathrm{M}$ pentobarbital
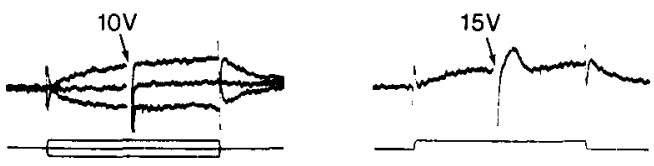

Normal
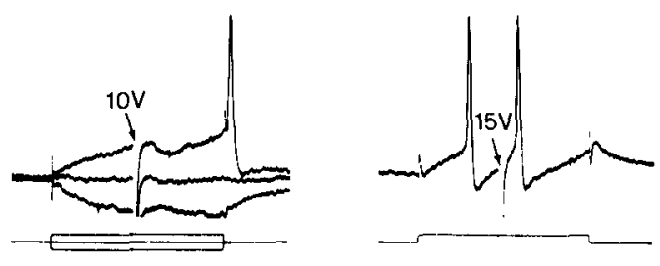

$\prod_{2 \mathrm{nA}}^{20 \mathrm{mV}}$

rent, which in normal saline caused a type I cell to fire repetitively, did not bring the cell to threshold (Fig. 12, left set of traces). In normal saline, the synaptic response with the lowest threshold was an IPSP, which could be elicited with a shock of $10 \mathrm{~V}$. A stronger shock elicited a suprathreshold EPSP, which obscured the IPSP (Fig. 12, top right). In the presence of 700 $\mu \mathrm{M}$ pentobarbital, no synaptic responses to a $10 \mathrm{~V}$ shock were recorded; the response with the lowest threshold $(15 \mathrm{~V})$ was an EPSP (Fig. 12, middle right). The changes resulting from application of pentobarbital were reversible (Fig. 12, bottom). This experiment showed that while the IPSP had the lower threshold in normal saline, pentobarbital raised the threshold of the IPSP above that of the EPSP. nerve document changes in the firing thresholds of its inputs.

In the presence of pentobarbital, intracellularly injected cur-

\begin{tabular}{|c|c|c|c|}
\hline $\begin{array}{l}\text { Cell } \\
\text { type }\end{array}$ & GABA & Glycine & IPSP \\
\hline I & $1 \mathrm{~mm}(+\rightarrow-)$ & Not measured & Not measured \\
\hline I & $2 \mathrm{mм}(+\rightarrow-)$ & $1 \mathrm{mM}(+) \rightarrow 5 \mathrm{mM}(-)$ & No change \\
\hline I & $1 \mathrm{mM}(+) \rightarrow 2 \mathrm{mM}(-)$ & $1 \mathrm{mM}(+) \rightarrow 5 \mathrm{~mm}(-)$ & No change \\
\hline II & $1 \mathrm{~mm}(+\rightarrow-)$ & $1 \mathrm{~mm}(+\rightarrow-)$ & Decreased \\
\hline II & $1 \mathrm{~mm}(+\rightarrow-)$ & {$[5 \mathrm{~mm}(-)]$} & Not measured \\
\hline II & {$[2 \mathrm{mM}(-), 5 \mathrm{~mm}(+)]$} & $2 \mathrm{mM}(+) \rightarrow 5 \mathrm{~mm}(-)$ & Not measured \\
\hline
\end{tabular}

Six cells whose sensitivity to bath-applied GABA and/or glycine was tested showed desensitization. Each row represents responses from 1 cell whose type is shown on the left. The symbol + indicates that a change in input resistance to the putative neurotransmitter at the given concentration was detected; the symbol - indicates that no change in input resistance was detected. Desensitization $(\rightarrow)$ was detected as a decrease in the sensitivity to GABA and glycine at a particular concentration $(+\rightarrow-)$ when compared with a response at a higher concentration. The relative amplitude of the synaptically driven IPSP before and after desensitization was detected is given in the right column. 


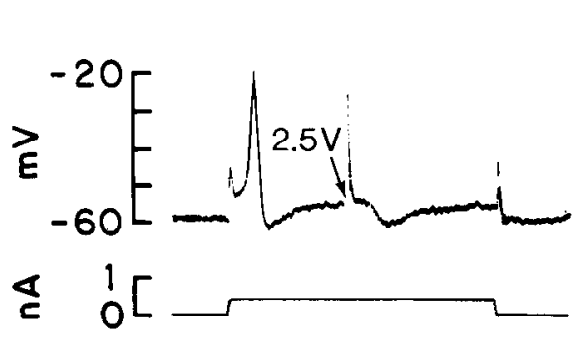

Normal

\section{$7 \times 10^{-4} \mathrm{M}$ pentobarbital}

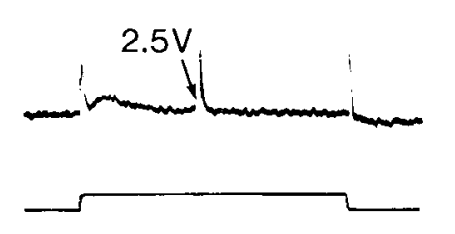

Normal

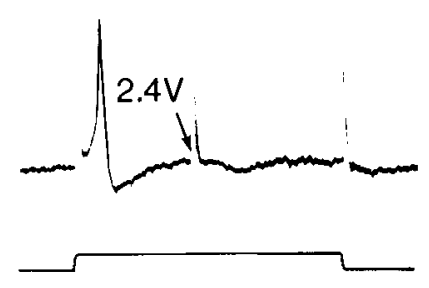

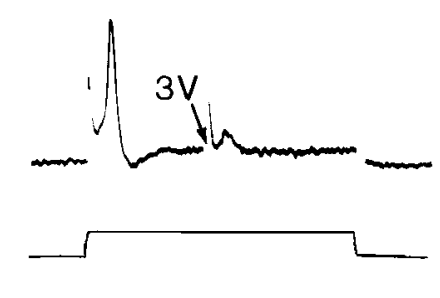
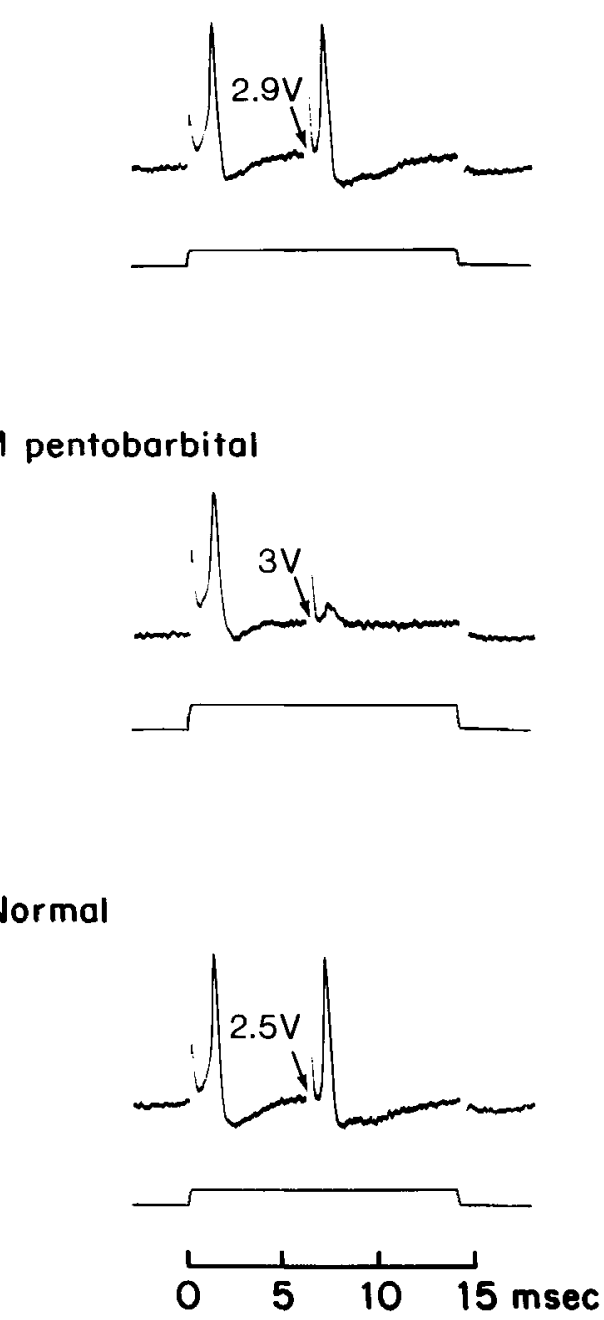

Figure 13. Barbiturate anesthetics raise the firing thresholds of a type II cell and of its inputs. Top, middle, and lower rows were recorded before, during, and after pentobarbital was applied, respectively. Responses to electrical stimulation of the auditory nerve were superimposed on responses to intracellularly injected current so that IPSPs could be seen clearly. Responses to intracellularly injected current show that the firing threshold of the cell was raised by pentobarbital; $0.35 \mathrm{nA}$ sufficed to cause the cell to fire before and after the application of pentobarbital (top and bottom rows), but $0.65 \mathrm{nA}$ was required to bring the cell to threshold in the presence of pentobarbital (middle row). Responses to electrical stimulation of the auditory nerve show that the thresholds of synaptic inputs were also raised by pentobarbital; the threshold of IPSPs was raised more than the threshold of EPSPs. Synaptic responses with the lowest thresholds were normally IPSPs (top and bottom, $l e f t)$. In the presence of pentobarbital, however, the response with the lowest threshold was an EPSP (middle row, right). The resting potential was not affected by pentobarbital. Action potentials have been retouched.
Similar changes were recorded from a type II cell (Fig. 13). More current was required to depolarize the cell to threshold. The top traces in Figure 13 show that an action potential could be elicited by $0.35 \mathrm{nA}$ in normal saline. In the presence of 700 $\mu \mathrm{M}$ pentobarbital, however, $0.35 \mathrm{nA}$ did not bring the cell to threshold (Fig. 13, middle left) but $0.65 \mathrm{nA}$ did (Fig. 13, middle right). The threshold returned to its original level when pentobarbital was washed out (Fig. 13, bottom traces). The threshold of both excitatory and inhibitory inputs were raised by pentobarbital. The IPSP had a lower threshold $(2.5 \mathrm{~V})$ than the EPSP, which at $2.9 \mathrm{~V}$ was suprathreshold (Fig. 13, top traces). In the presence of pentobarbital a shock of $2.5 \mathrm{~V}$ elicited no response (Fig. 13, middle left) and the synaptic response with the lowest threshold was an EPSP (Fig. 13, middle right). The changes in threshold of synaptic inputs were reversed when the pentobarbital was washed out (Fig. 13, bottom).

One conclusion that can be drawn from these experiments is that it is possible that anesthetics depress the inhibition intrinsic to the VCN at concentrations in the range used in in vivo experiments (see Discussion). The results of these experiments also support the idea that inhibition is mediated through a disynaptic pathway. When firing thresholds of a neuronal network are raised, multisynaptic pathways are more likely to fail than are monosynaptic ones because a failure to reach threshold at any stage will block the signal. Since thresholds of IPSPs are raised more than the thresholds of EPSPs, IPSPs are likely to be mediated through more synapses than EPSPs.

\section{Discussion}

The experiments described above are concerned with inhibition in the VCN. When the auditory nerve is stimulated electrically, postsynaptic cells in the brain stem respond with an initial EPSP, followed by an IPSP (Oertel, 1983). It has long been known that cells in the VCN are excited by sound. The observation that most cells in the VCN, both bushy and stellate cells (Wu and Oertel, 1984), are also inhibited as a result of activity in auditory nerve fibers is an unexpected finding.

Both GABA and glycine are candidates for roles as neurotransmitters that mediate inhibition. Our experiments tested whether either or both of these substances mediate the IPSPs we recorded in the VCN in slice preparations after the auditory nerve was stimulated. We conclude that glycine probably mediates the inhibitory circuitry that is preserved in the slices. GABA could mediate inhibition from parts of the brain that were cut away.

\section{Evidence that glycine is a neurotransmitter in the $V C N$}

Bushy and stellate cells are sensitive to bath-applied GABA and glycine. When GABA or glycine was added to the bath, cells responded with a transient hyperpolarization and a drop in input resistance. Dose-response curves show that, over a narrow range of concentrations of GABA and glycine, the input resistance of bushy and stellate cells drops to a level so low that it cannot be measured. The range of concentrations to which different cells 


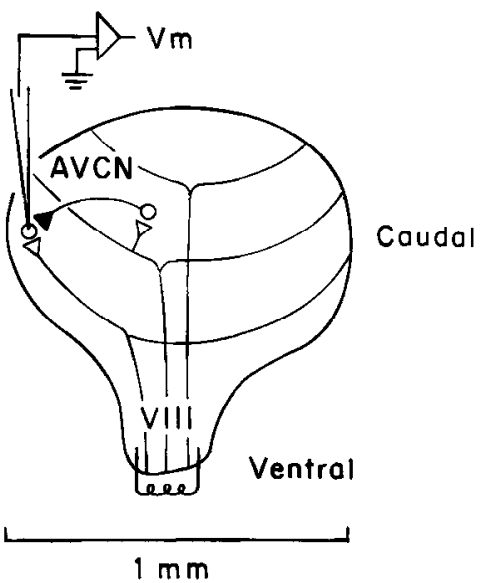

Figure 14. Diagram illustrating neuronal circuitry that could produce synaptic responses such as those recorded from slices of the VCN. In parasagittal slices of the most lateral parts of the VCN, cells from which recordings were made were probably contacted directly by terminals of auditory nerve fibers (open triangles) and by terminals of an inhibitory interneuron (filled triangle). Since EPSPs and IPSPs can be elicited separately, they were probably mediated by different auditory nerve fibers. The latency of IPSPs was cxpected to bc longer than that of EPSPs because inhibition was mediated through a disynaptic pathway, while excitation was mediated through a monosynaptic pathway. $V m$, Membrane voltage; $A V C N$, anteroventral cochlear nucleus.

are sensitive varies from cell to cell but usually lies between 0.1 and $5 \mathrm{~mm}$, the sensitivity to GABA being a little higher than the sensitivity to glycine. There was no systematic difference in sensitivity between bushy and stellate cells. The sensitivity of cells in the VCN to GABA and glycine generally resembled that of other cells in which tests of this kind have been made (Choi and Fischbach, 1981; Homma and Rovainen, 1978; Miller et al., $1981 \mathrm{a}, \mathrm{b}$ ). It is not clear why the sensitivity varied from cell to cell. Possibly cells varied in the number of receptors. However, on several occasions we observed clear desensitization of cells to bath-applied GABA and glycine, which was manifested as a lower sensitivity to later than to early applications. Although such clear desensitization was observed only rarely, more subtle desensitization could have affected dose-response curves.

The actions of GABA and glycine reflected in the dose-response curves, which ultimately produce changes in $\mathrm{Cl}^{-}$conductance, are complex and only incompletely understood. Since dose-reponse curves show that conductance changes are not linear functions of the log of the agonist concentration, cooperativity might be involved in the actions of GABA and glycine (Homma and Rovainen, 1978). GABA and glycine have separate receptors (Choi and Fischbach, 1981; Curtis, 1962; Curtis et al., 1968a, b, 1969, 1971a, b). However, because they can be cross-desensitized and because they have some $\mathrm{Cl}^{-}$conductance states in common, it has been suggested that different receptors may share a common ionophore (Barker and McBurney, 1979; Hamill et al., 1983). Furthermore, GABA receptors have been shown to be of more than one type (Alger and Nicoll, 1982; Simmonds, 1983). In neurons of the lamprey brain stem, it has been shown that the $\mathrm{Cl}^{-}$conductance produced by glycine is dccrcased by increases in the intracellular $\mathrm{Cl}^{-}$concentration (Gold and Martin, 1983).

The conductance change caused by the IPSPs must have the same ionic basis as the conductance change caused by the bathapplication of the neurotransmitter. Indeed, changes in the intracellular and extracellular chloride concentration caused parallel changes in the reversal potential of the IPSPs and the responses to bath-applied GABA and glycine (Figs. 2 and 8). When the intracellular chloride concentration was raised by recording intracellularly with $\mathrm{KCl}$-filled microelectrodes or when the extraccllular concentration of chloride was lowered, the IPSPs became depolarizing and bath-applications of GABA and glycine depolarized cells in the VCN. Thus GABA and glycine, like the IPSPs, mediate a change in the chloride conductance of cells in the VCN. This finding is consistent with what is known about GABA and glycine mediated inhibition in other cells (Adams and Brown, 1975; Choi and Fischbach, 1981; Homma and Rovainen, 1978; Miller et al., 1981a, b; Segal and Barker, 1984).

To distinguish which of these two putative neurotransmitters is more likely to mediate the IPSPs, the sensitivity of the IPSPs to various blockers was tested. Picrotoxin and bicuculline are blockers of GABA mediated inhibition, and strychnine is a blocker of glycine mediated inhibition (Belgum et al., 1984; Blume et al., 1981; Choi and Fischbach, 1981; Curtis, 1962; Curtis et al., 1968a, b, 1971 a, b; Miller et al., 198 1a, b; Takeuchi and Takeuchi, 1969). Picrotoxin and strychnine have been shown to be selective only at concentrations lower than $100 \mu \mathrm{M}$ (Choi and Fishbach, 1981). In slice preparations of the VCN, $1 \mu \mathrm{M}$ strychnine blocked IPSPs without exception, whereas $100 \mu \mathrm{M}$ picrotoxin and $100 \mu \mathrm{M}$ bicuculline generally did not block IPSPs. The occurrences of blocking of IPSPs by $100 \mu \mathrm{M}$ picrotoxin and bicuculline are presumably the result of nonspecific blocking at high concentrations (Biscoe et al., 1972; Choi and Fishbach, 1981; Curtis et al., 1969; Engberg and Thaller, 1970).

It is difficult to evaluate the only experimental observation that is not entirely consistent with glycine's being the neurotransmitter of the IPSPs in the VCN. It was shown that in 2 out of 3 cells in which such measurements were made, desensitization to bath-applied glycine and GABA was not accompanied by a reduction in the size of the IPSP (Table 4). It is possible, however, that the local concentration of neurotransmitter at the synapse was higher than the concentration of bath-applied glycine and GABA to which desensitization was observed. Perhaps the desensitization observed was of extrasynaptic receptors and synaptic receptors were not desensitized.

Most of the evidence presented above suggests that the IPSPs in the VCN that result from electrical stimulation of the auditory nerve are mediated by glycine. These results are consistent with the findings of various other types of experiments. Glycine is found in the cochlear nculei (Godfrey et al., 1977, 1978). It is taken up by some, but not all, of the terminals in the VCN (Schwartz, 1983); these electron-microscopic observations are consistent with glycine's being the transmitter contained in those terminals in which it is taken up. Several types of terminals, defined by the shapes and sizes of vesicles they contain, have been shown to terminate on bushy and stellate cells in the VCN. One such type of terminal, containing large, round vesicles, has been associated with endings of auditory nerve fibers (Cant, 1981; Cant and Morest, 1979b; Kane, 1973; Lenn and Reese, 1966; Tolbert and Morest, 1982b). The other types contain small round, small pleiomorphic, and large flattened vesicles (Cant, 1981; Cant and Morest, 1979b; Tolbert and Morest, 1982b). Neither the origins of the last 3 types of terminals nor their neurotransmitters have been determined or identified. It has been shown, however, that in the spinal cord, terminals labeled with tritiated glycine contain flattened vesicles (Matus and Dennison, 1971). Glycine has been shown to be released in a Ca-dependent way when tissuc of the cochlear nuclei is depolarized with high extracellular potassium (Wenthold, 1979). The release of glycine is not affected by cutting the auditory nerve. Iontophoretic applications of glycine suppress firing of cells in the VCN (Caspary et al., 1979).

\section{Neuronal circuitry}

What cells are stimulated by shocks to the auditory nerve in slice preparations? The auditory nerve contains several different 
types of fibers. The most abundant fibers are also the largest. The large, myelinated afferent fibers, 3-5 $\mu \mathrm{m}$ in diameter (Liberman, 1980), which carry signals from inner hair cells in the cochlea to the cochlear nuclei (Kiang et al., 1982), constitute $79 \%$ of the total number of fibers in mice (Ehret, 1979). The small, unmyelinated afferent fibers, less than $0.5 \mu \mathrm{m}$ in diameter, which reccive input from outer hair cells (Kiang ct al., 1982), constitute only $6 \%$ of the total number (Ehret, 1979). Efferent fibers running from the olivary complex to the cochlea are probably small and either myelinated or unmyelinated (Arneson and Osen, 1978; Paradiesgarten and Spoendlin, 1976). They make up $15 \%$ of the total number of fibers (Ehret, 1979). Because the largest fibers have the lowest thresholds to extracellular stimulation, it is likely that most, and perhaps all, of the synaptic responses described above result from activation of the large, myelinated afferent fibers.

It is unlikely that the IPSPs represent the monosynaptic input from the second of the 2 types of auditory nerve fibers. One would expect the small, unmyelinated fibers to conduct more slowly. At first glance, then, it seems possible that the IPSPs arise monosynaptically from inputs of the small, unmyelinated afferent fibers. In slice preparations there are differences in the lengths of the cut nerve and thus in the distance of the stimulating electrodes from postsynaptic cells; yet the latencies of IPSPs do not vary from preparation to preparation. Also, the small fibers would have higher thresholds for electrical stimulation with extracellular electrodes than the large fibers, yet the IPSPs often have lower thresholds than the EPSPs. Furthermore, if the small fibers used a different transmitter than the large fibers, one would expect the terminals of auditory nerve fibers to be of more than a single type. Studies of the ultrastructure of auditory nerve terminals show that only a single type of endings is affected by cutting of the auditory nerve (Lenn and Reese, 1966).

It is also unlikely that stimulation of efferent fibers resulted in the inhibition that we record in slices. Because the cochlear nuclei are innervated by collaterals of fibers of the olivocochlear bundle, the question arises as to whether antidromic activation of fibers of the olivocochlear bundle in the nerve could be responsible for the inhibition we recorded. There is little doubt that efferents of the olivocochlear bundle are cholinergic (Comis and Davies, 1969; McDonald and Rasmussen, 1971; Osen and Roth, 1969; Warr, 1975). Martin (1981) has shown that, in mice, collaterals that stain for AChE branch from the olivocochlear bundle and enter the cochlear nuclear complex at its medial edge. Since our slices are made with a parasagittal cut through the nucleus, most of the collaterals are severed from their parent axons in the nerve in our preparations. Until more is known about the efferent innervation from the olivary complex, as well as from other sources, in the cochlear nuclei of mice, the possibility that the inhibition we have recorded arises from circuitry associated with efferents cannot be completely excluded.

Too little is known about a group of cells that lies in the auditory nerve-the acoustic nerve nucleus-to determine whether these cells participate in the synaptic circuitry of the VCN. This group of cells is found in rats (Harrison and Warr, 1962) and in mice (Webster and Trune, 1982; Willard and Ryugo, 1983). When stained with cresyl violet, cells in the acoustic nerve nucleus resemble globular cells in the VCN, but most are somewhat larger. On the basis of this resemblance, Webster and Trune (1982) concluded that they were a displaced group of globular cells (i.e., bushy cells). Willard and Ryugo (1983), however, claim that these could not be displaced globular cells because they have different dendritic morphology and because they are labeled with HRP when injections are made into the inferior colliculus, while globular cells in the VCN are not (Ryugo et al., 1981; Willard and Ryugo, 1983). Whether cells of the acoustic nerve nucleus terminate in the VCN is not known.
When the auditory nerve is stimulated electrically, IPSPs are consistently recorded from cells in the VCN in brain slice preparations. Synaptic responses usually consist of early EPSPs and later IPSPs in bushy and stellate cells. As the voltage with which the auditory nerve is stimulated is gradually increased, presumably more and more fibers are caused to fire. Because EPSPs and IPSPs can be recorded separately, they must be mediated through different auditory nerve fibers. Because their thresholds are similar, it is likely that EPSPs and IPSPs are mediated through the same type of auditory nerve fiber. The latencies of IPSPs, which can be measured accurately only in the absence of EPSPs, are always longer (greater than $1.2 \mathrm{msec}$ ) than the latencies of EPSPs (0.6 or $0.7 \mathrm{msec}$ ) (Oertel, 1983). The simplest interpretation of these observations is that EPSPs represent direct excitation by auditory nerve fibers, and that the IPSPs result from excitation by other auditory nerve fibers of inhibitory interneurons (Fig. 14) (Oertel, 1983). The disproportionate increases in threshold of IPSPs in the presence of pentobarbital lend support to this idea (see below). The circuitry underlying these synaptic responses must, obviously, lie in the VCN since other parts of the brain are cut away in slice preparations. IPSPs are usually enlarged in a few discrete steps as the stimulating strength is increased, suggesting that, under the present experimental conditions, IPSPs are mediated through few cells. In many of the postsynaptic cells from which we recorded, the IPSPs had lower thresholds than EPSPs. One interpretation of this is that IPSPs arise from the activation of interneurons by different fibers of the same type, large auditory nerve fibers, that elicit EPSPs. This could be an experimental artifact of preferentially stimulating and recording from the most lateral parts of the nucleus, in slices that are consistently cut in the same way.

Stellate cells may mediate inhibition in the VCN. Intracellular injections with HRP have shown that at least some stellate cells have axon collaterals that terminate in the VCN (Rhode and Smith, 1982; Tolbert et al., 1982; Wu and Oertel, 1984). Bushy cells, by contrast, have a single large axon that leaves the cochlear nuclear complex without branching (Cant and Morest, 1979a; Tolbert et al., 1982).

The slice preparations also contain several cochlear granule cell domains. These regions contain two types of neurons, the granule cells and Golgi cells (Mugnaini et al., 1980a). Although the circuitry in which these cells take part is not completely understood, there is no evidence that supports their being involved in a local inhibitory circuit in the VCN. Granule cells and Golgi cells receive no direct input from auditory nerve fibers; granule cells project to the dorsal cochlear nucleus and Golgi cells appear to contact granule cells and perhaps other Golgi cells (Mugnaini et al. 1980b).

In cats, there is an anatomically distinct "small cell cap" that lies between the granule cell lamina and the principal cells of the VCN, dorsal to the nerve root. Because it is not clear whether and to what extent this region exists in mice (Mugnaini et al., 1980a), it is impossible to judge whether these cells might mediate inhibition.

\section{Effect of barbiturate anesthetics}

Anesthetics affect the cochlear nuclei profoundly (Evans and Nelson, 1973; Young and Brownell, 1976). In the dorsal cochlear nucleus, it has been clearly shown that inhibition is blocked by sodium pentobarbital (Evans and Nelson, 1973; Young and Brownell, 1976). In the AVCN, inhibition has not been shown as clearly to be blocked by anesthetics (Evans and Nelson, 1973). We tested the possibility that anesthetics might block the IPSPs in brain slice preparations of the VCN. At a concentration of $500 \mu \mathrm{M}$ or higher, pentobarbital raised the firing thresholds of auditory nerve fibers and postsynaptic cells. The dose usually given to cats is $40 \mathrm{mg} / \mathrm{kg}$ body weight. The concentration of a solution of $40 \mathrm{mg}$ sodium pentobarbital, dissolved in $1 \mathrm{~kg}$ water, 
would be $160 \mu \mathrm{M}$. Since the anesthetic is not spread evenly throughout the body, the concentration in extracellular fluids is probably in the concentration range given above.

In the presence of pentobarbital, more current was required to depolarize to threshold the cells that were impaled with microelectrodes; the strength of electrical shocks to the auditory nerve needed to evoke EPSPs in postsynaptic cells was also increased. The behavior of IPSPs did not parallel the behavior of auditory nerve fibers and postsynaptic cells. The IPSPs were either blocked or their thresholds were increased disproportionately; thus, even though in normal saline the IPSPs had a lower threshold than the EPSPs, in the presence of pentobarbital the EPSPs had the lower thresholds. It was difficult to judge whether the IPSPs were blocked or obscured by EPSPs, action potentials, and their undershoots.

If pentobarbital simply raises thresholds of cells without interacting with the IPSPs specifically, then these observations support the suggestion, made above, that IPSPs are mediated through a disynaptic pathway. In fact, raising the thresholds of cells has been used as a test to determine whether synaptic responses are monosynaptic or polysynaptic (Jansen et al., 1974). A multisynaptic pathway can be blocked by raising the thresholds of interneurons, whereas the failure of a monosynaptic pathway can be overcome by increasing the stimulus strength. The finding that the thresholds of IPSPs are increased more than the thresholds of EPSPs is evidence that IPSPs are mediated through a multisynaptic pathway only if there are no specific effects of pentobarbital on the IPSP. Barbiturates have been shown to activate GABA receptors but not glycine receptors (Aikin and Deisz, 1981; Higashi and Nishi, 1982; Jackson et al., 1982).

\section{Possible function of inhibition}

Recordings made from brain slices unfortunately do not provide many clues concerning the possible role of inhibition in the processing of auditory information. Although responses to sounds recorded in vivo in cats have shown that cells in the VCN are generally excited by sounds (Bourk, 1976; Evans and Nelson, 1973; Godfrey et al., 1975; Pfeiffer, 1966; Rhode et al., 1983; Shofner and Young, 1985; Young and Brownell, 1976), there is also considerable evidence that some cells in the VCN have response areas with inhibitory sidebands (Bourk, 1976; Brownell, 1975; Evans and Nelson, 1973; Goldberg and Brownell, 1973; Martin and Dickson, 1983; Shofner and Young, 1985). It is possible that the IPSPs recorded in brain slices mediate sideband inhibition.

Sideband inhibition is subtle in the VCN, especially in comparison with the dorsal cochlear nucleus, and may be present in only a subset of cells. Brownell (1975) recorded inhibitory sidebands from axons of globular bushy cells, but not from axons of spherical bushy cells, in the trapezoid body of cats. In comparison to cats, mice have small regions of large spherical cells and large regions of globular cells. Our slice preparations probably included large spherical cells only rarely; most of our recordings would have been made from globular cells. Shofner and Young (1985) showed that in two-thirds of the choppers, presumably stellate cells (Rhode et al., 1983), in the VCN in which such measurements could be made, responses to tones had inhibitory sidebands.

Intracellular recordings from cells in brain slices have revealed a prominent presence of IPSPs in many cells. These experiments showed unambiguously that inhibitory circuitry exists in the VCN of mice, but they did not reveal how weak or strong the inhibitory influence might be in response to tones. The inhibitory circuitry described in the present paper might mediate relatively subtle effects in the response patterns to sounds.

It is also possible that some of the effects of the inhibitory circuitry on responses to sounds in vivo might have been over- looked. Evans and Nelson (1973), Young and Brownell (1976), and the present experiments have shown that anesthetics reduce inhibition. In anesthetized preparations, therefore, inhibition will be weaker than in awake animals. Also, inhibitory sidebands are difficult to demonstrate with extracellular recordings in cells with little or no spontaneous firing.

IPSPs could have been missed in intracellular recordings from cells in the VCN. The present study shows that when $\mathrm{KCl}$-filled electrodes were used for recording intracellularly, IPSPs reversed so rapidly that hyperpolarizing IPSPs were never seen. Most published intracellular recordings from cells in the VCN have becn made with chloridc-containing microclectrodes (Rhode et al., 1983; Romand, 1978).

In bushy cells some investigators have found inhibitory sidebands consistently and others have not. Brownell (1975), recording from axons of bushy cells in the trapezoid body, found that globular cells consistently had sidebands. Bourke (1976) also found inhibitory sidebands in a small sample, but all bushy cells, which he tested ( $3 / 3$ cells) in extracellular recordings from the cochlear nucleus, where he identified bushy cells by the presence of prepotentials. On the other hand, Shofner and Young (1985), who also recorded extracellularly from bushy cells in the cochlear nucleus, found inhibitory sidebands only rarely in units whose response patterns or response waveform identify them as bushy cells. This inconsistency could be the result of different investigators recording from different subsets of cells, but it could also result from the use of different recording electrodes.

Usually extracellular electrodes record the firing of action potentials in nearby cells, and it has generally been assumed that recordings from bushy cells in the cochlear nucleus, too, reflect the firing pattern of those cells. Is it possible that in these cells whose excitatory synaptic inputs from the auditory nerve are unusually large, through somatic end-bulbs, and whose membrane properties are unusual (Oertel, 1983; Wu and Oertel, 1984), large electrodes record excitatory synaptic currents rather than currents associated with action potentials? If this were the case, the firing patterns of bushy cells recorded from axons would often but not always be the same as the patterns recorded with extracellular electrodes at the cell body. Inhibitory synaptic events, mediated through small, distributed synaptic boutons, would not be recorded even if they prevented excitatory synaptic currents from evoking an action potential at the axon hillock. If extracellular electrodes record excitatory synaptic currents, rather than action currents, the waveform of synaptically evoked responses should be different from the waveform of electrically evoked, antidromic action potentials. Bourke (1976) recorded responses to electrical stimulation of the trapezoid body at the cell bodies of bushy cells, but does not show the waveform of antidromic action potentials.

In conclusion, a survey of the literature shows that both bushy and stellate cells have inhibitory sidebands. The inhibitory sidebands are often subtle and may not be present in cells. It is possible that these inhibitory sidebands may be mediated through glycinergic interneurons intrinsic to the VCN, but this suggestion needs to be tested with further experiments.

\section{References}

Adams, D. R., and D. A. Brown (1975) Actions of gamma-aminobutyric acid on sympathetic ganglion cells. J. Physiol. (Lond.) 250: 85-120.

Adams, J. C., and E. Mugnaini (1984) GAD-like immunoreactivity in the ventral cochlear nucleus. Soc. Neurosci. Abstr. 10: 393.

Aikin, C. C., and R. A. Deisz (1981) Pentobarbitone interference with inhibitory synaptic transmission in crayfish stretch receptor neurones. J. Physiol. (Lond.) 315: 175-187.

Alger, B. E., and R. A. Nicoll (1982) Pharmacological evidence for two kinds of GABA receptor on rat hippocampal pyramidal cells studied in vitro. J. Physiol. (Lond.) 328: 125-141. 
Arneson, A. R., and K. K. Osen (1978) The cochlear nerve in the cat: Topography, cochleotopy, and fiber spectrum. J. Comp. Neurol. 178: 661-678.

Barker, J. L., and R. N. McBurney (1979) GABA and glycine may share the same conductance channel on cultured mammalian neurones. Nature 277; 234-236.

Belgum, J. H., D. R. Dvorak, and J. S. McReynolds (1984) Strychnine blocks transient but not sustained inhibition in mudpuppy retinal ganglion cells. J. Physiol. (Lond.) 354: 273-286.

Biscoe, T. J., A. W. Duggan, and D. Lodge (1972) Antagonism between bicuculline, strychnine and picrotoxin and depressant amino acids in the rat central nervous system. Comp. J. Gen. Pharmacol. 3: 423433 .

Blume, H. W., Q. J. Pittman, and L. P. Renaud (1981) Sensitivity of identified medial hypothalamic neurons to GABA, glycine and related amino acids; influence of bicuculline, picrotoxin and strychnine on synaptic inhibition. Brain Res. 209: 145-158.

Bourk, T. R. (1976) Electrical responses of neural units in the anteroventral cochlear nucleus of the cal. Ph.D. thesis, MIT, Cambridge, MA.

Brawer, J. R., D. K. Morest, and E. C. Kane (1974) The neuronal architecture of the cochlear nucleus of the cat. J. Comp. Neurol. 155: 251-300.

Brownell, W. E. (1975) Organization of the cat trapezoid body and the discharge characteristics of its fibers. Brain Res. 94: 413-433.

Cant, N. B. (1981) The fine structure of two types of stellate cells in the anterior division of the anteroventral cochlear nucleus of the cat. Neuroscience 6: 2643-2655.

Cant, N. B., and D. K. Morest (1979a) Organization of the neurons in the anterior division of the anteroventral cochlear nucleus of the cat. Light-microscopic observations. Neuroscience 4: 1909-1923.

Cant, N. B., and D. K. Morest (1979b) The bushy cells in the anteroventral cochlear nucleus of the cat. A study with the electron microscope. Neuroscience 4: 1925-1945.

Caspary, D. M., D. C. Havey, and C. L. Faingold (1979) Effects of microiontophoretically applied glycine and GABA on neuronal response patterns in the cochlear nuclei. Brain Res. 172: 179-185.

Choi, D. W., and G. D. Fischbach (1981) GABA conductance of chick spinal cord and dorsal root ganglion neurons in cell culture. J. Neurophysiol. 45: 605-620.

Comis, S. D. (1970) Centrifugal inhibitory processes affecting neurones in the cat cochlear nucleus. J. Physiol. 210: 751-760.

Comis, S. D., and W. E. Davies (1969) Acetylcholine as a transmitter in the cat auditory system. J. Neurochem. 16: 423-429.

Comis, S. D., and I. C. Whitfield (1968) Influence of centrifugal pathways on unit activity in the cochlear nucleus. J. Neurophysiol. 31: 62-68.

Curtis, D. R. (1962) The depression of spinal inhibition by electrophoretically applied strychnine. Int. J. Neuropharmacol. 1: 239-250.

Curtis, D. R., L. Hosli, and G. A. R. Johnston (1968a) A pharmacological study of the depression of spinal neurones by glycine and related amino acids. Exp. Brain Res. 6: 1-18.

Curtis, D. R., L. Hosli, G. A. R. Johnston, and I. H. Johnston (1968b) The hyperpolarization of spinal motoneurones by glycine and related amino acids. Exp. Brain Res. 5: 235-258.

Curtis, D. R., A. W. Duggan, and G. A. R. Johnston (1969) Glycine, strychnine, picrotoxin and spinal inhibition. Brain Res. 14:759-762.

Curtis, D. R., A. W. Duggan, D. Felix, and G. A. R. Johnston (1971a) Bicuculline, an antagonist of GABA and synaptic inhibition in the spinal cord. Brain Res. 32: 69-96.

Curtis, D. R., A. W. Duggan, D. Felix, G. A. R. Johnston, and H. McLennan (1971b) Antagonism between bicuculline and GABA in the cat brain. Brain Res. 33: 57-73.

Ehret, G. (1979) Quantitative analysis of nerve fiber densities in the cochlea of the house mouse (Mus musculus). J. Comp. Neurol. 183: $73-88$.

Engberg, I., and A. Thaller (1970) On the interaction of picrotoxin with GABA and glycine in the spinal cord. Brain Res. 19: 151-154.

Evans, E. F., and P. G. Nelson (1973) The responses of single neurones in the cochlear nucleus of the cat as a function of their location and anaesthesic state. Exp. Brain Res. 17: 402-427.

Godfrey, D. A., N. Y. S. Kiang, and B. E. Norris (1975) Single unit activity in the posteroventral cochlear nucleus of the cat. J. Comp. Neurol. 162; 247-268.

Godfrey, D. A., J. A. Cartcr, O. H. Bergen, and F. M. Matschinsky (1977) Quantitative histochemical mapping of candidate transmitter amino acids in cat cochlear nucleus. J. Histochem. Cytochem. 25. 417-431.

Godfrey, D. A., J. A. Carter, O. H. Lowry, and F. M. Matschinsky (1978) Distribution of gamma-aminobutyric acid, glycine, glutamate and aspartate in the cochlear nucleus of the rat. J. Histochem. Cytochem. 26: 118-126.

Gold, M. R., and A. R. Martin (1983) Analysis of glycine-activated inhibitory post-synaptic channels in brain-stem neurones of the lamprey. J. Physiol. (Lond.) 342: 99-117.

Goldberg, J. M., and W. E. Brownell (1973) Discharge characteristics of neurons in anteroventral and dorsal cochlear nuclei of cat. Brain Res. 64: 35-54.

Hamill, O. P., J. Bormann, and B. Sakmann (1983) Activation of multiple-conductance state chloride channels in spinal neurones by glycine and GABA. Nature 305: 805-808.

Harrison, J. M., and W. B. Warr (1962) A study of the cochlear nuclei and ascending auditory pathways of the medulla. J. Comp. Neurol. 119: 341-380.

Higashi, H., and S. Nishi (1982) The effect of barbiturates on the GABA receptor of cat primary afferent neurones. J. Physiol. (Lond.) 332: 299-314.

Homma, S., and C. M. Rovainen (1978) Conductance increases produced by glycine and gamma-aminobutyric acid in lamprey interneurons. J. Physiol. (Lond.) 279: 231-252.

Jackson, M. B., H. Lecar, D. A. Mathers, and J. L. Barker (1982) Single channel currents activated by gamma-aminobutyric acid, muscimol, and (-) - pentobarbital in cultured mouse spinal neurons. J. Neurosci. 2: 889-894.

Jansen, J. K. S., K. J. Muller, and J. G. Nicholls (1974) Persistent modification of synaptic interactions between sensory and motor nerve cells following discrete lesions in the central nervous system of the leech. J. Physiol. (Lond.) 242: 289-305.

Kane, E. C. (1973) Octopus cells in the cochlear nucleus of the cat: Heterotypic synapses upon homeotypic neurons. Int. J. Neurosci. 5: 251-279.

Kiang, N. Y. S., D. K. Morest, D. A. Godfrey, J. J. Guinan, Jr., and E. C. Kane (1973) Stimulus coding at caudal levels of the cat's auditory nervous system. I. Response characteristics of single units. In Basic Mechanisms in Hearing, A. R. Møller, ed., pp. 455-478, Academic, New York.

Kiang, N. Y. S., J. M. Rho, C. C. Northrop, M. C. Liberman, and D. $\mathrm{K}$. Ryugo (1982) Hair cell innervation by spiral ganglion cells in adult cats. Science $217: 175-177$.

Lenn, N. J., and T. S. Reese (1966) The fine structure of nerve endings in the nucleus of the trapezoid body and the ventral cochlear nucleus. Am. J. Anat. 118: 375-390.

Liberman, M. C. (1980) Morphological differences among radial afferent fibers in the cat cochlea: An electron-microscopic study of serial sections. Hear. Res. 3: 45-63.

Martin, M. R. (1981) Acetylcholinesterase-positive fibers and cell bodies in the cochlear nuclei of normal and reeler mutant mice. $J$. Comp. Neurol. 197: 153-167.

Martin, M. R., and J. W. Dickson (1983) Lateral inhibition in the anteroventral cochlear nucleus of the cat: A microionotophoretic study. Hear. Res. 9: 35-41.

Martin, A. R., J. W. Dickson, and J. Fex (1982) Bicuculline, strychnine and depressant amino acid responses in the anteroventral cochlear nucleus of the cat. Neuropharmacology 21: 201-207.

Matus, A. I., and M. E. Dennison (1971) Autoradiographic localization of tritiated glycine at "flat vesicle" synapses in spinal cord. Brain Res. 32: 195-197.

McDonald, D. M., and G. L. Rasmussen (1971) Ultrastructural characteristics of synaptic endings in the cochlear nucleus having acetylcholinesterase activity. Brain Res. 28: 1-18.

Miller, R. F., T. E. Frumkes, M. Slaughter, and R. F. Dacheux (1981a) Physiological and pharmacological basis of GABA and glycine action on neurons of mudpuppy retina. I. Receptors, horizontal cells, bipolars, and G-cells. J. Neurophysiol. 45: 743-763.

Miller, R. F., T. E. Frumkes, M. Slaughter, and R. F. Dacheux (1981b) Physiological and pharmacological basis of GABA and glycine action on neurons of mudpuppy retina. II. Amacrine and ganglion cells. J. Neurophysiol. 45: 764-782.

Moore, J. K., and R. Y. Moore (1984) GAD-like immunoreactivity in the cochlear nuclei and superior olivary complex. Soc. Neurosci. Abstr. 10:843.

Mugnaini, E., W. B. Warr, and K. K. Osen (1980a) Distribution and 
light microscopic features of granule cells in the cochlear nuclei of cat, rat and mouse. J. Comp. Neurol. 191: 581-606.

Mugnaini, E., K. K. Osen, A. L. Dahl, V. L. Friedrich, Jr., and G. Korte (1980b) Fine structure of granule cells and related interneurons (termed Golgi cells) in the cochlear nuclear complex of cat, rat and mouse. J. Neurocytol. 9: 537-570.

Oertel, D. (1983) Synaptic responses and electrical properties of cells in brain slices of the mouse anteroventral cochlear nucleus. J. Neurosci. 3: 2043-2053.

Oertel, D. (1985) Use of brain slices in the study of the auditory system: Spatial and temporal summation of synaptic inputs in cells in the anteroventral cochlear nucleus of the mouse. J. Acoust. Soc. Am. 78: 328-333.

Osen, K. K. (1969) Cytoarchitecture of the cochlear nuclei in the cat. J. Comp. Neurol. 136: 453-484.

Osen, K. K. (1970) Course and termination of the primary afferents in the cochlear nuclei of the cat. Arch. Ital. Biol. 108: 21-51.

Osen, K. K., and K. Roth (1969) Histochemical localization of cholinesterases in the cochlear nuclei of the cat, with notes on the origin of acetylcholinesterase-positive afferents and the superior olive. Brain Res. 16: 165-185.

Paradiesgarten, A., and H. Spoendlin (1976) The unmyelinated nerve fibers of the cochlea. Acta Otolaryngol. 82: 157-164.

Pfeiffer, R. R. (1966) Classification of response patterns of spike discharges for units in the cochlear nucleus: tone burst stimulation. Exp. Brain Res. 1: 220-235.

Rhode, W. S., and P. H. Smith (1982) An analysis of HRP stained cells in the ventral cochlear nucleus of the cat. Soc. Neurosci. Abstr. 8: 347.

Rhode, W.S., D. Oertel, and P.H. Smith (1983) Physiological response properties of cells labeled intracellularly with horseradish peroxidase in cat ventral cochlear nucleus. J. Comp. Neurol. 213: 448-463.

Romand, R. (1978) Survey of intracellular recording in the cochlear nucleus of the cat. Brain Res. 148: 43-65.

Ryugo, D. K., F. H. Willard, and D. M. Fekete (1981) Differential afferent projections to the inferior colliculus from the cochlear nucleus in the albino mouse. Brain Res. 210: 342-349.

Schwartz, I. R. (1983) Differential uptake of $\mathrm{H}^{3}$-amino acids in cat cochlear nucleus. Am. J. Otol. 4: 300-304.

Segal, M., and J. L. Barker (1984) Rat hippocampal neurons in culture:
Properties of GABA-activated $\mathrm{Cl}^{-}$ion conductance. J. Neurophysiol. 51: $500-515$.

Shofner, W. P., and E. D. Young (1985) Excitatory/inhibitory response types in the cochlear nucleus: Relationships to discharge patterns and responses to electrical stimulation of the auditory nerve. J. Neurophysiol. 54: 917-939.

Simmonds, M. A. (1983) Multiple GABA receptors and associated regulatory sites. Trends Neurosci. 6: 279-281.

Takeuchi, A., and N. Takeuchi (1969) A study of the action of picrotoxin on the inhibitory neuromuscular junction of crayfish. J. Physiol. (Lond.) 205: 377-391.

Tolbert, L. P., and D. K. Morest (1982a) The neuronal architecture of the anteroventral cochlear nucleus of the cat in the region of the nerve root: Golgi and Nissl methods. Neuroscience 7: 3013-3030.

Tolbert, L. P., and D. K. Morest (1982b) The neuronal architecture of the anteroventral cochlear nucleus of the cat in the region of the cochlear nerve root: Electron microscopy. Neuroscience 7: 3053-3067.

Tolbert, L. P., D. K. Morest, and D. A. Yurgelun-Todd (1982) The neuronal architecture of the anteroventral cochlear nucleus of the cat in the region of the cochlear nerve root: Horseradish peroxidase labelling of identified cell types. Neuroscience 7: 3031-3052.

Warr, W. B. (1975) Olivocochlear and vestibular efferent neurons of the feline brain stem: Their location, morphology and number determined by retrograde axonal transport and acetyl-cholinesterase histochemistry. J. Comp. Neurol. 161: 159-182.

Webster, D. B., and D. R. Trune (1982) Cochlear nuclear complex of mice. Am. J. Anat. 163: 103-130.

Wenthold, R. J. (1979) Release of endogenous glutamic acid, aspartic acid and GABA from cochlear nucleus slices. Brain Res. 162: 338343.

Willard, F. H., and D. K. Ryugo (1983) Anatomy of the central auditory system. In The Auditory Psychobiology of the Mouse, J. F. Willot, ed., pp. 201-304, Charles C Thomas, Springfield, IL.

Wu, S. H., and D. Oertel (1984) Intracellular injection with horeseradish peroxidase of physiologically characterized stellate and bushy cells in slices of mouse anteroventral cochlear nucleus. J. Neurosci. 4: 1577-1588.

Young, E. D., and W. E. Brownell (1976) Responses to tones and noise of single cells in dorsal cochlear nucleus of unanesthetized cats. J. Neurophysiol. 39: 282-300. 